\title{
Developmental states: a review of the literature
}

\author{
Laura Routley ${ }^{1}$
}

February 2012

${ }^{1}$ University of Manchester, UK

Email correspondence: laura.routley@manchester.ac.uk

ISBN: 978-1-908749-07-9 


\begin{abstract}
This paper conducts a review of the literature concerning developmental states, in order to identify gaps and suggest research questions which could be fruitful for the Effective States and Inclusive Development Research Consortium to explore, within the remit of their proposed research programme. This literature review attends to three key questions about developmental states and the answers proposed to them within the literature, namely; what worked? Why did it work? And would it work elsewhere? It also examines an emerging literature suggesting other models of a developmental state more suited to contemporary circumstances, which focus more explicitly on development as a social phenomenon rather than as a purely economic one. These are of particular interest given ESIDs focus on inclusive development.
\end{abstract}

The conclusions of the paper examine some of the gaps in the literature and suggest an agenda for future research which includes addressing questions around:

- How does the consensus of conducting developmental roles come about - and how is it sustained?

- Patrimonialism, personal rule, development and stability

- Role of education, especially higher/further education

- Importance of rural/agriculture policies

Keywords: Developmental States, Inclusive Development, New Developmental States, Patrimonialism,

\title{
Acknowledgements
}

I would like to acknowledge the very useful and encouraging comments from the two anonymous reviewers of the paper. The development of the paper was greatly aided by my discussions of the topic with Prof. Adrian Leftwich and I would like to thank him for his insightful inputs. Dr. Sam Hickey, ESID Research Director, also provided welcome comments and advice. 


\section{Contents}

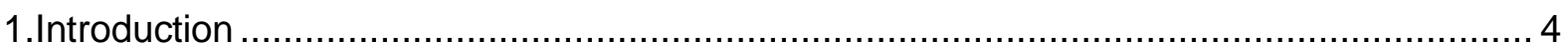

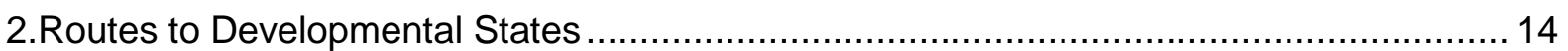

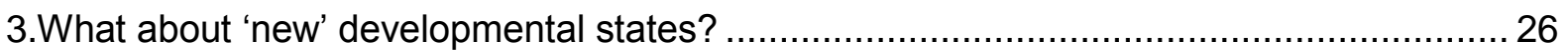

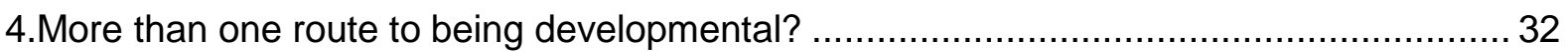

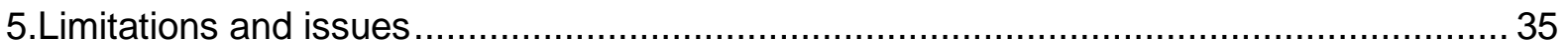

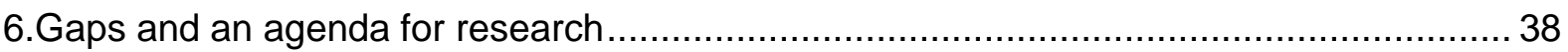

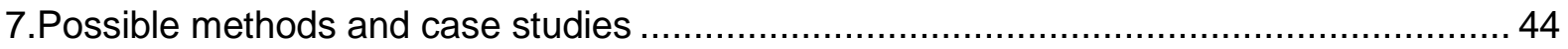

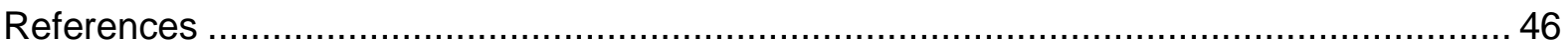

Appendix 1 - Previous research on Developmental States: summary of key empirical studies

53

Appendix 2 - Statistics on developmental and potential developmental states ..................56

\section{Tables}

Table 1 - Breakdown of states discussed as developmental 10

Table 2 - Tertiary enrolment (\% change) over decades - top 5 Developmental States 37 


\section{Introduction}

This paper conducts a review of the literature concerning developmental states, in order to identify gaps and suggest research questions which could be fruitful for the Effective States and Inclusive Development Research Consortium to explore, within the remit of their proposed research programme. The limitations of this papers scope in terms of both geography and the theoretical critique of the literature are due to the paper being directed to speak to this research programme. Examining the possible significance of this literature for ESID this review explores the larger question of whether and how the developmental state combines elements of an effective state and inclusive development. In other words whether, the developmental state can be seen as a model which provides a route to social justice and economic prosperity for a broad spectrum of the states population and whether this model could be utilised outside of the East Asian states, to which the term was first applied.

While the term developmental states was initially and is still, frequently used to describe countries such as Japan, South Korea, Taiwan, Singapore and Viet Nam, which have experienced rapid economic growth through state-led policies or interventions. It has also been used to refer to a much wider group of countries both by academics and politicians and this paper will address a broader sweep of these later. Moreover, the state playing a key role in development can be seen to be applicable to a wider array of countries' experiences which have not been or have only recently been discussed as developmental states. Some of these instances are very informative, but employ different terminology such as Social Democracy (Sandbrook et al. 2007). ${ }^{1}$ Whilst this paper is a broad review of the literature there is a regional bias in the paper towards Asia and Africa due to ESID's focus on these regions. Literature from outside these regions has not be ignored but has not been explored in as much depth. Therefore much more could have been said about Europe's historical experience of developmental states (see: List, 1904; Gregor 1979) and the more contemporary experiences of Latin America $^{2}$ than is possible to fully cover here.

Academic explorations of East Asian developmental states and their experiences, as well as the concept of the developmental state more broadly, have generally placed a new emphasis on the role of the state in achieving economic growth and poverty reduction. This emphasis on the significant role of the state in successfully achieving economic growth conflicts with the neo-liberal market focused assumptions about how to promote development that many development actors had been working with. Rather than seeing the state as the agent which could act to produce growth, these neo-liberal approaches saw the state as part of the problem and pushed to reduce its size and influence in order for development to take off.

One of the central debates around developmental states has focused on the controversy over how and, indeed if, states should intervene in the market, and what role the state should play in development (White and Wade 1988). Johnson (1999) recalls the hostility with which his notion of a developmental state was received by Anglo-American economists (p.34) and discusses how the Japanese experience he described was 'inconvenient' for both sides of the ideological cold war divide (p.49). These debates have gradually shifted to an acceptance of the significance of the states' role, but the nature of this role continues to be argued over (Kohli 1994, p.1269). As Evans says in his seminal book on embedded autonomy, the question is not how much state intervention, but 'what kind' (Evans 1995,

\footnotetext{
${ }^{1}$ The work of Sanbrook et al on cases in Kerala, Costa Rica and Chile is a key part of this highly informative literature.

${ }^{2}$ There is some literature which compares the development progress of East Asia and Latin America - see Rains and Orrock 1985 and Jenkins 1991.
} 
p.10). The research developmental states has come to be seen by some as a refreshing move away from such value laden arguments to examine historically and empirically 'what has worked' (Fritz and Menocal 2007, p.531). This review examines this question of 'what has worked' in terms of examining the social and political aspects of what has worked rather than entering into a detailed engagement with those debates concerning different industrial policies, or returning to the initial contentions between the market liberalisation and state intervention perspectives. This decision was made so that the political and social elements of developmental states can be more clearly brought into focus. Within this political focus (which of course includes some economic elements, as the two are not easily separated) this literature review attends to three key questions and the answers proposed to them within the literature, namely; what worked? Why did it work? and would it work elsewhere?

There is an expansive and expanding literature which centres on two broad questions. The first centres on understanding the processes that produced developmental states; How did developmental states achieve their successes in economic development? What worked, and why? The second question centres on the possibilities for other states to learn from developmental states, and asks how (if at all) the lessons of developmental states can be utilised by other developing states: would it work elsewhere? These have not been the only questions posed by scholars, but they do encompass much of the recent discussion in its broadest terms. These questions structure this review, which begins by exploring the explanations of what factors produced developmental states before moving on to consider debates around how new developmental states can be built. The final section of the review, however, is structured by asking some more specific questions about what this literature tells us, what gaps it is yet to cover and what further research it usefully points towards. This section will also ask how useful the term 'developmental states' is and whether future research could usefully take forward scholars' analyses of the great variety of ways developmental states achieved their successes without tying itself to the desire for a model.

\section{Methodology: how was the review of the literature conducted?}

This review of the literature on developmental states emerges out of and builds on a systematic literature search. Subject searches were carried out using key search engines to identify relevant materials. The key search engines used were the International Bibliography of the Social Sciences (IBSS database), and the Governance and Social Development Resource Centre (GSDRC) document library, and these were complemented by searches using Google Scholar. The search terms used was simply 'developmental states'. Extra literature was added to this systematically gathered baseline from the works identified in the gathered literature as key works which make novel arguments. A full account of the literature gathered in this manner can be found in the Developmental States section of the annotated bibliography.

In addition, a table is provided in Appendix 1 of previous research conducted on developmental states with summaries of each study and its findings.

\section{What is a state?}

The state is a concept which is highly significant for the disciplines of politics, international relations, political sociology, as well as anthropology and development studies (amongst others). It is therefore perhaps inevitable that it is also highly contested. In this brief introductory section I do not intend to resolve these debates and provide a clear answer to the question 'what is the state', after all "fifty years of asking the question [what is the state] have not produced any very satisfactory or even widely agreed answers" (Abrams 1988, p.59). The intervening twenty or so years since Abrams article was published have not 
resulted in any revolutionary progress on this question. However, Weber's conceptualisation of the state is widely used as a starting point for discussions on the question of the state. Weber defined the state as "a human community that (successfully) claims the monopoly of the use of physical force within a given territory" (Weber 1991, p.78). Aspects of this definition are seen as vitally important for current debates about state capacity which often examine the failure of the declared states to successfully claim monopoly over the use of force or at least to do so throughout the whole of its declared territory. ${ }^{3}$

Weber's definition, however, does not give clear guidance on issues such as where society stops and the state starts, attributing the monopoly of violence to a 'human community', but also acknowledging that there are groups within a state (Weber 1991, p.78). The reason for this I would suggest is that Weber saw the state as a relation of "men dominating men" (although given my own preference for including women as political actors maybe we can think of it as a 'people dominating people') but he considered there to be a number of different forms of dominance or authority (Herrschaft) ${ }^{4}$ (Weber 1991, p.78; Weber 1978). These various forms of dominance or authority do not necessarily draw the same boundaries between 'state' and 'society', neither do they work to the same ends or conduct the same tasks (Weber 1991, p. 78; Weber 1978). ${ }^{5}$ However, the state-society division is often seen as vital for many scholars of politics even as it is seen as profoundly blurred or even nonexistent for theorists such as Althusser and Gramsci (Cohen and Arato 1994, p.159; Trouillot 2001 , p. 127). The centrality of the state-society division can be seen in what Hobson describes as 'the first state debate' in international politics which pitched those advancing a 'state-centric' problematic against a 'society-centric' problematic', although Hobson regards it as a debate which has been in many senses transcended by a focus on "how state structures and social forces mutually constitute each other" (Hobson 2001, p.396). Timothy Mitchell highlights that the significance of state - society and state - market distinctions is that their production is about the creation and maintenance of a particular order (Mitchell 2006, p.175). This first state debate and the wider ideological political discussions it fed into can be seen to have shaped the normative prescriptions and theoretical assumptions about state and society which have pervaded development theory's ideas of the state (Petiteville,1998). The more recent shift towards considering the complex mutual constitution of state and society, and the way in which the production of this boundary is about the maintenance of a particular order may benefit the developmental states literature which has tended to possess a state-centric focus which assumes a boundary without much interrogation of it.

Clearly the state as a term is highly contested. However, for clarity within this paper generally the term 'the state' implies something which is beyond merely government, but which does not encompass the whole of a country (Trouillot 2001, p.127). The emergent conception of the state in the developmental state literature sees the state as incorporating executive, legislative and judicial branches, but also bureaucratic functions and ministries; something beyond merely government but with discernable if blurred boundaries (cf. Gupta 1995). Business, civil society and political society lie outside as aspects of society in this understanding of the state. Moreover, state-society relations also play an important role in the narrative of developmental states, their success often being seen to rest on a very particular form of state-society relations that Evans terms embedded autonomy (1995). The

\footnotetext{
${ }^{3}$ Some of these discussions are examined in Matthias vom Hau's ESID paper on state capacity so I will not go into details about these debates here.

${ }^{4}$ Herrschaft does not translate very easily from the German and is tied into notions of legitimacy in some of Weber's work (Roth 1968, p.195)

${ }^{5}$ Weber saw the state's essence to reside in its legitimate use of physical violence. However, later theorists, notably Foucault, have argued that it is not only physical violence that is used to govern or discipline (Foucault 1995).
} 
state within these accounts does not however always remain a unified cohesive entity; rather many scholars examine the relationship not only of developmental states to their societies but also examine how different parts of the developmental state, the executive and the bureaucracy for example, interact with each other (Johnson 1982, Ramseyer and Rosenbluth 1993; Haggard 2004). There is also differentiation between different ministries, or other bureaucratic units, and in some cases exploration of their interactions (Johnson, 1982). Despite the differentiation of elements within the state, the state is in many senses seen as a entity which should remain impermeable and avoid 'capture' by particular societal interests. ${ }^{6}$ However it is useful to remember that this impermeable entity does not 'exist' per se (Trouillott 2001, p126). Rather it is produced through a large highly complex set of social relations both within the defined territory of 'the state' and without. Whilst the ephemeral nature of the state as an entity may be apparent, the state is used throughout the developmental state literature and in this review as useful shorthand for a set of processes and institutions which act as a form of domination or authority that produces particular sets of outcomes - in this case developmental ones.

\section{What are developmental outcomes?}

If a developmental state is one which produces developmental outcomes - what is development? What counts as a developmental outcome is highly contestable. Surprisingly, it had received relatively little debate in the developmental states literature until more recently. Within the literature developmental states have been mainly associated with economic growth (Mkandawire, 2001). Often however it was growth that was seen to have other social benefits and the concept of a developmental state is often used to denote not only states which have achieved significant growth rates but rather growth rates alongside with a perception of reasonably wide spread legitimacy (Leftwich 2000, pp.166-167). Scholars have highlighted that there has generally been significant increases in the standard of living for a large number of the population in developmental states (Johnson 1987, p.143 and Leftwich 2008, p16). The legitimacy of developmental states rested on these significant improvements in standards of living for a broad cross section of society, and are also seen to be a significant element of developmental states (Wade 1990, p.7; Fritz and Menocal 2007, p.534; Lin and Monga 2011, p.278). So the central elements of the developmental outcomes for much of the developmental states literature was growth, with widespread increases in the standard of living (thorough increased employment and industrialisation in the case of East Asia and Mauritius) and broad based legitimacy. The emphasis placed on these various aspects varies between scholars and indeed scholars often focus on different elements - growth, living standards, legitimacy - at different junctures.

These progressive elements have however frequently been accompanied by politically repressive regimes and the exclusion of certain groups (Leftwich 1995, pp.418-419;). Although developmental states have often had comparatively good (or at least not extremely bad) human rights records (Leftwich 1995, pp418-419). Developmental states would therefore not fully fulfil ESIDs conceptualisation of inclusive development. ${ }^{7}$ Later in the review we will return to the tension between these developmental outcomes and ESID's concern with inclusive development, and to the work of scholars whose concepts of what kind of developmental state is needed in the future focuses on different understandings of developmental outcomes (Sandbrook et al. 2007; Evans 2010; 2011). Some argue for democratic developmental states (White 1998; Edigheji 2005 2011). Evans recent work

\footnotetext{
${ }^{6}$ Although Lockwood does see state capture as possibly offering a way to transcend clientelism (Lockwood 2005, p. 120)

ESID's working definition of Inclusive Development is: Inclusive development involves the equitable distribution of capability achievement across society, with capabilities defined in both individual and collective terms, in line with the broader achievement of social justice and the public good.
} 
builds on Amartya Sen's capability approach to focus on the development of capabilities of individuals rather than economic gains as the focus of the developmental state (Evans 2010, 2011) The work of Richard Sandbrook et al identifies states as a key player in development, but sees the developmental outcomes of these state-led projects to centre on building a society without poverty and social exclusion (Sandbrook et al. 2007).

\section{How to identify a developmental state? Definitions, methods and disagreements}

Scholars started to define and elaborate the concept of a developmental state in response to their explorations of the economic growth stories of countries in South East Asia, and this particular experience has tended to dominate the framing of the concept (Johnson 1982; 1987 and Evans 1995). Although there were a number of previous examples of economic growth in which the state has been seen to be the key actor. The political theorist most commonly associated with the first argument for the importance of state-led development is Friedrich List who argued that Germany needed to take a state-led approach to development to 'catch up' with Great Britain (List 1904, cf. White and Wade 1988, p.1; Leftwich 2000, p.155).

The centrality of the East Asian 'miracle' to the developmental states literature means this review spends some time considering the multiplicity of arguments over what the key conditions were which precipitated their success, and their becoming (or becoming identified as) developmental states. However, Johnson notes that the concept also exists as an abstract generalisation (Johnson 1999, p.43). In the abstract the developmental state refers to the synthesis of otherwise very particular specifics of each East Asian case into a model, an ideal type, of the developmental state. Johnson's own Japanese model was perhaps the first of these typologies (Johnson 1982, pp. 305-324). The precise composition of the attributes associated with developmental states varies. However, for the purpose of this review I will summarise these as being

1. A capable, autonomous (but embedded) bureaucracy (Evans, 1995).

2. A political leadership oriented towards development (Musamba, 2010; Fritz and Menocal 2007).

3. A close, often mutually beneficial symbiotic relationship between some state agencies (often discussed as pilot agencies) and key industrial capitalists. (Johnson, 1982; 1987).

4. Successful policy interventions which promote growth (Wade, 1990; Beeson, 2004).

In addition to this summary, one of the key distinctions within the literature which I argue is central to understanding developmental states emerges from Vu's work (2007, p.38), namely that between developmental structures and developmental roles. The definition of developmental states on which this review is based is a definition of a state which possesses developmental structures (state capacity) and uses these to perform developmental roles. The necessity of capacity and leadership/vision in combination is echoed by other scholars as well (Fritz and Menocal, 2007). What I find useful about $\mathrm{Vu}$ is that he highlights how both of these elements can also exist separately of each other, whilst they are still needed in combination for a developmental state to be successful. So my working definition is that: $A$ developmental state has sufficient state capacity to be effective in its targeted areas and has a developmental vision such that it chooses to use this capacity to work towards economic development. - In other words, it has developmental structures and performs developmental roles.

Whilst this is the definition utilised here, there are other ways to conceive of the developmental state. Usually, those states identified as developmental states have been successful in achieving marked levels of growth. Sometimes developmental states are identified primarily on their achievement of economic growth. This association between the 
form of the state and its resultant success means that it is hard to identify developmental states prior to their attainment of successful growth (Fritz and Menocal 2007, p. 534). Moreover, some scholars have argued that the terms risk being tautological "...since evidence that the state is developmental is often drawn deductively from the performance of the economy" (Mkandawire 2001, p.290). He argues that for the term to mean anything there has to be the possibility for the state to be developmental but not achieve economic growth due to unforeseen external shocks (Mkandawire 2001). In other words, there has to be the possibility for there to be failed developmental states.

There is, however, some literature which discusses precisely what Mkandawire is concerned about, namely, failed developmental states (Herring, 1999). The discussion of failed developmental states rests on defining the developmental states not by their successes but by their commitment to a widely held ambition - a hegemonic ideology - of development (Woo-Cummings, 1999). This definition of the developmental state separates off one of the two elements that $\mathrm{Vu}$ argues needs to be present for developmental policies to be pursued. First, states need to possess developmental structures and second, they need to perform (or attempt to perform) developmental roles (Vu 2007, p.28). This effectively separates out the political will to follow developmental policies from the capacity to implement these policies. Vu highlights how at certain points the Indonesian state was in this position of attempting to pursue developmental roles without having developmental structures, so by this definition and at this point in time, Indonesia would be a developmental state - but a failing one. This definition is useful as it allows for failure, makes the definition of developmental states less tautological and also emphasises the significance of this driving communal goal - often associated with nationalism (Woo-Cummings 1999, Johnson 1999). Yet, a full exploration of developmental states also needs to engage with the developmental structures utilised to perform as a successful developmental state. These two elements, structures and developmental commitment are required together.

In relation to ESID's research this separation of structures and roles is significant. For what Vu discusses as structures can basically be seen as the capacity of the state to be effective - in that it can enact and achieve the aims it sets. However, this effectiveness does not necessarily translate into a developmental state - let alone an inclusive developmental state, without being oriented toward such ends. However the establishment of effective states is seen as a prerequisite for the development of a developmental state (Leftwich 2008, p.12). As Vu highlights, with the example of Indonesia, without state capacity attempts to perform developmental roles will flounder (2007).

Another element utilised to identify developmental states is their ability to 'upgrade'. Doner, Ritchie and Slater highlight this ability to "upgrade from lower value to higher value economic activities" as the key element which marked out South Korea, Singapore and Taiwan as developmental states, as opposed to the four high-growth countries of the Association of South Asian Nations namely; Malaysia, Thailand, the Philippines and Indonesia (2005, p.328). Evans also contends that the aims of developmental states are to occupy better niches higher up in the global division of labour hierarchy (1995, pp.7-8) Whilst this definition can be seen as useful in highlighting the significant gains from upgrading, it narrows the definition of the developmental state. Countries such as Botswana, despite their growth, would not be seen to be developmental by this definition, as they have struggled to diversify the economy let alone 'upgrade' (Taylor 2005, p.54).

The usage of the term developmental states remains predominately associated with East Asian states which have been successful in achieving prolonged high rates of growth. There has, however, been interest in the usefulness of the developmental state approach for other regions, perhaps Africa in particular (Meyns and Musamba 2010, p.7). The narrow regional focus of developmental states is contested in a number of ways; Mkandawire contends that 
there were developmentally focused states in Africa in the immediate post colonial period (Mkandawire 2001) and other scholars have identified states that have been patrimonial developmental at certain times (Kelsall and Booth, 2010). There are also other states outside of East Asia that are regularly identified as developmental states - perhaps most prominently, Botswana. However, the term remains profoundly associated with the East Asian post World War Two experience.

Therefore, and despite Botswana's frequent identification as a developmental state, the aim of Mkandawire's article is to refute the assumption that African states are not capable of being developmental. This brings us to the heart of one of the major issues of this review which considers the discussion on the 'transferability' of the developmental states' lessons outside of East Asia. There is a considerable ongoing debate about the usefulness of the 'east Asian model' being utilised in other contexts - which will be discussed below. In addition to this examination of the usefulness of the developmental state format as traditionally associated with the pattern of development associated with East Asia and focused on economic growth - albeit with considerable social gains - for other states within the contemporary context. Is an emerging literature examining not this model of the developmental state, but suggesting other models of a developmental state more suited to contemporary circumstances and which focus more explicitly on development as a social phenomenon rather than as a purely economic one (Evans, 2010; 2011; Sandbrook et al. 2007). These are of particular interest given ESIDs focus on inclusive development.

\section{Which states are developmental?}

Alongside and intertwined with discussions about what defines a developmental state are debates and disagreements about which states are included within the bracket of developmental states definition. A section of the literature is precisely concerned with laying out why particular states (particularly some African states) fit or do not fit the developmental state model (Gyimah-Boadi, 2009 [Ghana]; Taylor, 2005 [Botswana]; Meynes, 2010 [Botswana]; Meisenhelder, 1997 [Mauritius]; Lockwood, 2005; [Botswana, Uganda, Ghana, Tanzania, Mosambique]; Howell 2006 [China]). The table below lays out how different states or groups of states have been discussed within the developmental state literature and in relation to the developmental state model. The table reflects an attempt to clearly lay down how the literature understands particular states or groups of states in relation to the concept of the developmental state. Whilst this review concentrates on states there is an expanding literature on the sub-national developmental state - some of the regions identified are not strictly speaking states (or at least their statehood is debated) these areas have been entered into the states column but are in brackets. ${ }^{8}$ In addition the developmental nature of the state is not, a static status, and some states may be developmental for a limited or transitory period. Some states have therefore been identified as developmental during a discrete era and this is denoted in the table by giving the dates in brackets (Fritz and Menocal, 2007).

\footnotetext{
${ }^{8}$ This review has not had the space to explore this sub-national developmental states literature fully. For more information on this emerging literature see Hutchinson 2008 and Bateman et al. 2011.
} 
Table 1 - Breakdown of states discussed as developmental

\begin{tabular}{|c|c|c|c|}
\hline States & Description & Attributes & References \\
\hline $\begin{array}{l}\text { Japan, } \\
\text { South Korea, } \\
\text { (Taiwan) }\end{array}$ & $\begin{array}{l}\text { The Big Three - Japan is often seen as the first developmental } \\
\text { state, both in terms of its prior uptake of 'developmental state } \\
\text { attributes and having been the first state to which the label was } \\
\text { applied (Johnson 1982). Despite variations between the three, } \\
\text { the similarities of South Korea and Taiwan's strategies to each } \\
\text { other and to Japan means that they are often seen to cohere as a } \\
\text { group and are often seen as the model developmental states. }\end{array}$ & $\begin{array}{ll}- & \text { Industrial based economy } \\
\text { - } & \text { High economic growth rates } \\
\text { - } & \text { Professional bureaucracy } \\
\text { - } & \text { Autonomous state } \\
& \text { bureaucracy }\end{array}$ & $\begin{array}{l}\text { Johnson 1982; Amsden } \\
\text { 1989; Wade 1990; } \\
\text { Woo-Cumings, 1999; } \\
\text { Chang } 2006\end{array}$ \\
\hline $\begin{array}{l}\text { Malaysia, } \\
\text { Indonesia, } \\
\text { Thailand and } \\
\text { Philippines }\end{array}$ & $\begin{array}{l}\text { South Asian Developmental States - These states also } \\
\text { achieved significant economic growth around the same period as } \\
\text { 'The Big Three'. However their growth levels were not quite so } \\
\text { high and they were seen to have a less autonomous state } \\
\text { bureaucracy and seen by some to have more issues with } \\
\text { corruption - although not to have become predatory states. }\end{array}$ & 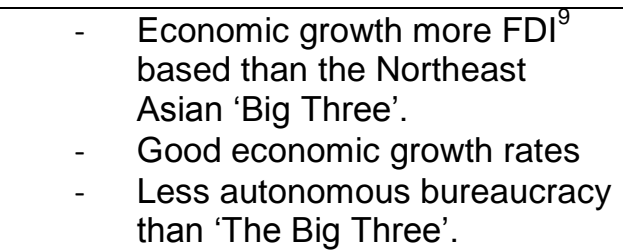 & $\begin{array}{l}\text { Chang 2006; Doner, Ritchie } \\
\text { and Slater 2005; Hayashi } \\
\text { 2010; Jomo 2004; }\end{array}$ \\
\hline Botswana & $\begin{array}{l}\text { Botswana is frequently held up as an example of an African } \\
\text { developmental state. What perhaps marks Botswana out more } \\
\text { starkly however is the natural resource based economy on which } \\
\text { this developmental state has been built. }\end{array}$ & $\begin{array}{ll} & \text { Good economic growth rates } \\
\text { - } & \text { Natural resource based } \\
\text { economy } \\
\text { - Democratic (de facto one party } \\
\text { state) }\end{array}$ & $\begin{array}{l}\text { Mbabazi and Taylor, 2005; } \\
\text { Meyns, } 2010 .\end{array}$ \\
\hline $\begin{array}{l}\text { Mauritius, } \\
\text { Chile, } \\
\text { Costa Rica } \\
\text { (Kerala) }\end{array}$ & $\begin{array}{l}\text { Social Democratic Developmental States - These are states } \\
\text { which have achieved a reasonable level of economic growth but } \\
\text { have also invested heavily in reducing poverty and social } \\
\text { exclusion. They are also democratic and have a fairly open } \\
\text { political space. }\end{array}$ & $\begin{array}{ll}- & \text { Reasonable economic growth } \\
\text { rates } \\
\text { - } \quad \text { Democratic } \\
\text { - } \quad \text { State investment in social } \\
\text { protection, health and } \\
\text { education }\end{array}$ & Sandbrook et al. 2007 \\
\hline
\end{tabular}

${ }^{9}$ FDI - Foreign Direct Investment 


\begin{tabular}{|c|c|c|c|}
\hline States & Description & Attributes & References \\
\hline China $^{10}$ & $\begin{array}{l}\text { China's recent impressive economic success has led a number of } \\
\text { scholars to see it as having been in line with the developmental } \\
\text { state model since the mid 1980s (Evans 2011). }\end{array}$ & $\begin{array}{ll}- & \text { Good growth rates } \\
- & \text { State investment in } \\
\text { Infrastructure, Education and } \\
\text { Health } \\
\text { - } & \text { Sustained Economic Growth }\end{array}$ & $\begin{array}{l}\text { Jian-xing and De-jin, 2010; } \\
\text { Howell 2006, (cf.White } \\
\text { 1988b) }\end{array}$ \\
\hline
\end{tabular}

${ }^{10}$ There is a growing literature on China as a developmental state - however due to space and time constraints this review has not engaged with this literature in detail. This is in part due to the fact that it is an attempt to see if the model applies to the Chinese case rather than literature which radically develops the concept of the developmental state. 


\section{How developmental states have been interrogated: What does the literature look like?}

The developmental state is essentially a model of a particular type of state first laid out by Chalmers Johnson out of his analysis of the Japanese state's role (especially of course MITI - the Ministry of International Trade and Industry that was the focus of his research) in the economic 'miracle' that it had achieved. Johnson himself however acknowledges that "analytically speaking, the issue still remains that it is hard to abstract a "model" from historical reality" (Johnson 1999, p.43). The majority of the content of Johnson's influential book on this subject was in many senses an institutional history of MITI. This is perhaps a good example of the most prevalent way in which developmental states have been interrogated - a detailed examination of a particular country's political, economic and bureaucratic history from which an attempt to produce, augment, amend or refute a model or theory is undertaken. Wade's book, Governing the Market, can also be seen to be in this vein. Focusing on the industrial policies undertaken in Taiwan, Wade utilises his analysis of these political and economic events and practices to refute neo-classical claims that the developmental states of East Asia were a victory for the market and to interrogate further the types of interventions which Taiwan undertook into its economy and business sector (Wade 1990).

In addition to these case study approaches, scholars such as Vu and Evans undertake comparative work to speak to key questions about the roots of and the mechanisms of developmental states (Evans, 1995; Vu, 2007). By examining the political and economic development of countries whose developmental trajectory has differed but which have some commonalities this comparative work is utilised to highlight the points of similarity and difference in order to isolate key driving factors behind the emergence of developmental states. In these instances $\mathrm{Vu}$ generates an argument about the overwhelming significance of elite mass relations for the emergence of developmental states and Evans develops the concept of embedded autonomy (which will be discussed in detail in the Capable, Bureaucracy and Embedded Autonomy section below) (Vu, 2007; Evans, 1995).

Ongoing research by the Tracking Development project increases the scale of this comparative work by examining pairs of countries from East Asia and sub-Saharan Africa. ${ }^{11}$ They have been able to broaden their observations to more regional comparisons (Kees van Donge, Henley, and Lewis, 2009). The work of Kees van Donge, Henley and Lewis whilst highly relevant to the developmental state debates, is not however attempting to engage with the developmental state model per se. They are rather examining the divergence between development trajectories of countries in the East Asian region and sub-Saharan Africa. They explore political and economic changes through an historical examination and relate these to growth figures and other changes in order to assess their impacts - in particular the impact of agricultural policies. In so doing they aim to explore the possible causes for the different developmental trajectories of these regions.

The types of evidence that these case studies and comparative studies draw upon include historical, journalistic, and personal accounts of events; statistics; government policy and documents; and previous literature discussing and analysing similar issues. However, these scholars differ in their approach to analysing this evidence in terms of what elements or scales they focus on. No author is myopic enough to focus solely on one scalar level but many lean to one level or another. The vast majority of the developmental states literature has focused on the 'national' level, something which is critiqued by Pempel as domestic

\footnotetext{
${ }^{11}$ The pairs that they examine are: Nigeria - Indonesia; Kenya - Malaysia; Tanzania - Viet Nam; and Uganda Cambodia. More information about this project can be found at http://www.trackingdevelopment.net/
} 
events and decisions take place within a broader regional and global context (Pempel 1999, pp.146-7). In this vein the actors whom they have focused on have generally been state level bureaucratic institutions, the government and large commercial industrial organisations they have interacted with. There are however, more recent attempts to examine instances of developmentalism at a more local level (Howell, 2006; Hutchinson, 2008).

These methods of approach examining the details of developmental states are accompanied by two other types of literature concerning developmental states. The first is an attempt to refine the model of the developmental state not in relation to a particular case but as a general attempt to hone the model and make it more useful. Adrian Leftwich's work is probably the most prominent of this type (Leftwich 1995; 2000). The second mode of addressing developmental states is to examine states in reference to the developmental state model to evaluate if they fit it (Meyns, 2010; Lockwood, 2005; Meisenhelder 1997; Howell 2006).

Finally, there are critiques of the term evaluating its impact, the problems with the approach and the usefulness of the model (Moon and Prasad, 1994; Woo-Cumings,1999; Pempel, 1999; Johnson, 1999); as well as works which attempt to prescribe or evaluate how the developmental state could be a useful model for some countries development in the future (White 1998; Musamba 2010). Peter Evans has also recently laid out what he calls the 21st century developmental state which varies in key ways from the 20th century developmental state and offers a different set of prescriptions for states wishing to follow a developmental route (Evans, 2010; Evans, 2011).

One area of critique which the literature on the developmental state does not engage directly is broader critiques of academic attempts at producing models - although there is some acknowledgement of the significance of contingency and context in terms of the difficulties of applying the developmental state model in new contexts. Many of the more profound reservations about the problematic nature of modelling the social and political world (e.g. Livingstone 1992) are absent from the discussions of the developmental state as a concept within the literature - although they do discuss the applicability of this particular model in different contexts. Similarly, more in-depth discussions about the production of the statesociety divide (see. Gupta and Sharma 2006, Mitchell 2006) are frequently left to one side. This literature review does not deal with these issues fully. This is not because they are not vital - they are - but rather because the review interrogates this literature in many senses on its own terms and makes research suggestions which fit with the ESID research programme. This review, therefore, is not the place for further interrogation and critique of the underlying basis of the developmental states literature.

\section{Routes to Developmental States}

\section{How do states become developmental?}

Much of the literature on developmental states examines the routes which states have taken to become 'developmental' in order to identify the key elements which enabled them to be successful. It is not however only their 'success', often understood in terms of growth, which we are concerned with. There are many different routes to achieving economic growth (Williams et al. 2011), but here we are concerned with one particular path to growth/development identified in the literature as the developmental state. This literature, however, remains incredibly diverse in what it identifies as the key conditions for a successful developmental state to emerge. Of course, the diversity of these accounts is indicative of the lack of consensus in the literature on the key aspects of the routes that states have taken to become developmental, but it may equally reflect the variety of routes 
states have taken. These varying accounts can often be seen to emerge out of different case studies with, for example, a scholar who examined elite politics in South Korea and Indonesia (Vu, 2007) coming to very different conclusions to one who explored the formation of political coalitions in Botswana (Poteete, 2009). But of course, these different analyses can also emerge from different scholar's interests, world views and theories. Whilst more recent work comparing larger numbers of countries (Kees van Donge et al. 2009) may assist in moving away from explanations which apply only to certain cases, they may miss some of the nuances that detailed single case studies are able to illuminate.

This section sets out some of the conditions highlighted in the literature as significant for the emergence of developmental states. Many authors do not advocate mono-causal explanations, and in many cases there is considerable consideration of the interaction between different elements and the necessity for two or more conditions to coincide. I have tried to highlight these interactions and interdependencies, however, I apologise if separating these conditions into discrete categories may obscure some of these nuances. In addition, it is a potentially foolish task to try to isolate the 'cause' or even the two or more conditions that combined together form the 'cause' of the significant economic growth and developmental state formations of East Asia. Pempel argues that, in fact, economic growth in the region was analytically 'overdetermined' and that "Numerous forces triangulated to make the isolation of some single, super cause all but impossible..." (1999, p.138).

There are often questions of sequencing around the factors that influence the emergence of a developmental state. Colonialism, for example, is seen as a foundational experience from which some developmental states have emerged rather than a later attribute. Agricultural and land reform are also seen to be precursors to the emergence of the industrial developmental states of East Asia which have come to be seen as the archetype of a developmental state. One significant study on this topic is the work of the 'Tracking Development' programme which has examined longer term trends than are often looked at and particularly highlighted the importance of agricultural development and land reform before undertaking industrialisation (Kees van Donge, Henley, and Lewis 2009, p.7). Further work by David Henley, however, highlights that part of the significant impact of these agricultural activities was in the number of people that these development strategies reached, their ability to meet and responsiveness to immediate needs, and their focus on results. (Henley, undated). Heneley's analysis emphasises the marginal importance of detailed planning and can be seen to highlight the organic contingent nature of how developmental states have emerged, over a designed, planned, set of stages. Sequencing is also a difficult question arround many of the attributes of developmental states which both produce and are produced by developmental states, for example; a capable bureaucracy and embedded autonomy or a national project/state legitimacy. Whilst sequencing questions are difficult Vu's work shows that the pre-existence of certain state capacities are important, and highlights how attempts to perform developmental roles without developmental structures being in place flounder ( $\mathrm{Vu}$ 2007). However, the presence of developmental structures, what could be called state capacity, but no willingness to perform developmental roles equally fails to result in developmental outcomes (Vu 2007). This sequencing is also complicated by the fact that the structures or capacities of the state to conduct developmental roles can be constructed through a developmental state drive; thus undermining any simplistic sequential logic.

The explorations of different conditions below should not therefore be read as a list of discrete alternative explanations, or as a list of variables which combine with each other in a predictable, sequential way to produce discrete (and foreseeable) outcomes. Rather, this is a listing of the various factors which are seen within the literature to be significant for the emergence of developmental states. My examination begins by looking at some of the historical conditions that it is argued impacted upon developmental states in East Asia. It 
then broadens out to examine elements scholars have identified as particularly important to the developmental states. These discussions will of course feed into the later section which addresses the possibilities for building developmental states.

\section{Contexts / preconditions}

\section{The colonial experience}

Scholars have often argued that there is a deeply embedded link between the colonial experience and the post-decolonisation development trajectory of a state (Young 1988; 1995). These arguments have been applied to the states of South Korea and Taiwan in ways which highlight continuities of institutions and practices between the period of colonisation by Japan in the first half of the twentieth century with their subsequent rapid economic growth in the second half (Haggard, Kang and Moon 1997, p.867). Two elements of Japanese colonialism identified as having had a significant impact were changes to the state structure and institutions, and the pattern of business-government relations, both of which are seen as key aspects of the developmental state, as will be discussed in further detail below (Haggard, Kang and Moon 1997, p.868).

The institutional legacy and the establishment of a capable bureaucracy have been seen as significant elements of colonial legacies in the case of developmental states, due to their influence on state formation, especially the Japanese influence on Korea and Taiwan. Acemoglu, Johnson and Robinson have argued that the institutions instituted (or not) by colonisers had a profound impact on economic development (Acemoglu, Johnson and Robinson, 2000). They contend that the development of institutions was, in part, initiated by the form of colonialism in terms of how extractive it was based on settlement patterns of those from the colonising states. Vu argues that the Dutch colonial influence on Indonesia left a much less developmental institutional legacy than that which Japan left in Korea (2007, p. 31). The divergent legacies and the fact that there were high levels of Japanese settlers in Korea during Japan's colonisation of the country, seems to support Acemoglu, Johnson and Robinson's assertion that institutions were built where there were more settlers from the colonial power (Acemoglu, Johnson and Robinson 2000; Vu 2007, p. 31). Japanese colonialism, according to these scholars, seems to have been a likely impetus for the later emergence of a developmental state bureaucracy in Korea and, by extension, Taiwan. In addition to this institutional legacy, Kohli argues that the patterns of alliances between propertied classes and the state during Japanese colonialism can be seen to offer precedents which were later drawn upon by Korea as a developmental state (Kohli 2004, p.48). Moreover, he contends, Korea underwent significant industrialisation under Japanese colonialism that was considerably state-directed, which again provided a distinctive colonial legacy (Kohli 2004, pp.48 -56). Korean industrialisation under Japanese colonialism is, according to Kohli, “... nearly unique in the comparative history of colonialism" (2004, p.48).

However, Kohli's arguments for the distinctiveness of Japan's colonial interventions are contested (Booth 2005, pp.3-5). Booth points out that industrialisation was not unique to Korea and Taiwan and other East Asian colonies also underwent industrial development to varying degrees (Booth 2005, pp.9-11). Korea was also still a predominately agricultural economy at the end of Japanese colonialism (Haggard, Kang and Moon 1997, p.871). Whilst Japanese policy in Korea may have been conducive to Korean business in some limited instances, it is argued that it was predominantly geared towards the interests of Japanese companies and often worked to impede the emergence of Korean enterprise (Haggard, Kang and Moon 1997, pp.875-6). The continuity of the bureaucratic structures and institutions is also disputed, both on grounds of the exaggeration of the continuity of personnel within the bureaucracy (Haggard, Kang and Moon 1997, p.874); and due to the wider presence of effective administrative structures in other East Asian colonies which did 
not go on to become developmental states in the same form as Korea and Taiwan (Booth 2005, p.12).

Korea and Taiwan did, however, have high levels of infrastructure relative to other East Asian colonies (Booth 2005, p.14), although much of this infrastructure (especially industrial infrastructure) was destroyed during World War Two and the Korean Peninsular war (Haggard, Kang and Moon 1997, p.872). Some Korean entrepreneurs did also obtain experience of running industrial enterprises under Japanese colonial rule (Haggard, Kang and Moon 1997, p.868), which can be seen as a foundational element for the emergence of a developmental state (Amsden 2011, p.294).

A number of these scholars emphasise the importance of post decolonisation political decisions and events over the colonial experience in governing these states' growth trajectories (Poteete 2009; Haggard, Kang and Moon, 1997; Booth 2005). Other scholars have also suggested in the case of Botswana that pre-colonial elements were influential (Hjort, 2010). Vu sees the colonial period as having had an influence but regards the post decolonisation intra-elite and elite mass relations as more significant for Korea's formation as a state, and subsequently its economic and social development than the colonial legacy (Vu 2007). His take is perhaps the one found implicitly in much of the literature on developmental states which regards the colonial history as a factor but not the most significant or relevant one. The impact of the Japanese colonial legacy, therefore, remains disputed but it is perhaps most informative in terms of what elements of the legacy are seen as significant, namely the bureaucracy, state-business relations and industrialisation, as these areas are seen as central for developmental states.

\section{Geo-political context - the Cold War}

Colonialism is not the only significant historical contextualising element. Whilst the global context in which developmental states emerged has sometimes been overlooked in preference for examining the domestic structures of the state, it plays a significant role (Evans 1995, p.6; Pempel 1999, pp.146-7; Wade 1990, p.346). It can be argued that the emergence of the central core of East Asian developmental states cannot be understood outside of the cold war context and particularly their relationship with America. Interestingly, the same cold war context has been seen as detrimental to those states in Africa in the immediate post-independence era that had developmentally -focused leaders (Fritz and Menocal 2007, p.535). The most highly successful East Asian developmental states, Taiwan, South Korea and Japan, were all particularly strategically significant for the U.S. during the cold war period (Pempel, 1999) and all of these states received diplomatic, financial and in some cases military aid from America (Leftwich 2008, p16; Pempel 1999, p 153 and p173; Fritz and Menocal 2007, p.542;). Perhaps most significantly, Japan, Korea and Taiwan gained access to American markets for their products (Pempel 1999, p177). Whilst not due to the same geo-political considerations, Mauritius' negotiated access to European Union markets has been seen as similarly significant for the states' ability to successfully industrialise (Meisenhelder 1997, p.283). Access to the Japanese market was also important for Korea and Taiwan.

The broader global context has perhaps had less attention paid to it as these elements are in some senses less under the control of the 'developmental states' and, of course, less replicable as a model. It was not only the cold war per se but wider impacts of global and regional trends that impacted the ability of the core developmental states to evolve:

“...unintended, contingent factors have played an important role in conditioning the economic fate of East Asian countries; the Korean war and the Vietnam war for Japan; the Vietnam war and the middle East oil boom for South Korea; strong 
yen and subsequent benefits for South Korea and Taiwan" (Moon and Prasad 1994, p.370).

The impact of these broader events is often difficult to measure. Yet they were a key part of the global context in which the industrial and export strategies of the developmental states thrived. In addition, how these events impacted states cannot be divorced from the agency of the states involved, as Evans highlights, opportunities being available does not necessarily mean that states will take them up (1995, p.6).

\section{National security threats}

The role of external threats as a catalyst for the emergence of developmental states has been commented on by a number of scholars. The advent of many states taking on a developmental form occurred in an environment of threats to the state's survival (Doner, Ritchie and Slater, 2005). Leftwich, for example, describes Botswana as surrounded by hostile neighbours (Leftwich 2010, p.98). Botswana was also seen to be at risk of being swallowed by its larger neighbour, South Africa. Japan was also emerging from a significant war and the mobilisation towards development is seen to have been a result of the population not being de-mobilised following the war, just re-focused (Johnson 1999, p.41). External threats have thus often been seen as a key part of the context out of which developmental states emerge.

It is not however only external threats which have shaped the environment of developmental states. Many developmental states have also faced the threat of internal unrest (Doner, Ritchie and Slater, 2005). Meridith Woo-Cumings comments that the possibility of war defined South Korea and Taiwan's state-society relations and refers to them as "two places born of civil wars which have not ended" (1999, p.10). One aspect of this - discussed shortly - is the idea that in some senses the developmental state was a strategy of growth that worked, in part, to quell internal unrest. Repression was also widely used by authoritarian developmental states reflected in their sometimes poor, although not as bad as many countries, human rights records (Leftwich 1995, p.166). Vu discusses at length the history of repression of communists and labour movements in South Korea; however, he contrasts this strategy with of that of mass-incorporation in Indonesia (2007).

These threats, both internal and external, can provide incentives for cooperation between elites. Elite commitment to developmental states is, therefore, frequently seen to emerge at crisis points (Leftwich 2008, p.12; Fritz and Menocal 2007, p.534). Poteete's analysis of Botswana contends that, in part, the formation of Botswana's political coalition was successful in part due to external vulnerability to its dominating neighbour South Africa (Poteete 2009, pp. 556-7). However, as Vu highlights in his comparison of South Korea and Indonesia, how elites and governments respond to these internal and external threats can vary, as can the type of political coalition that may be formed in response (something which is discussed further in the Political Settlement section below). The impacts of these various responses are political but also profoundly economic as Doner, Richie and Slater contend: "How war makes states depends ultimately on how war makes states generate revenue" (2005, p.339).

Whilst strategies and responses are always contingent, for Doner, Ritchie and Slater, a particular combination of three factors are a necessary and sufficient cause for developmental states to emerge, namely; a credible threat of internal strife, external threats, and resource constraints in combination. They contend that the pressures of needing to maintain political coalitions due to internal threats, with limited resources available due to the scarcity of these resources to use rents to achieve this, combined with the need for foreign exchange due to the external threats, produces sufficient cause for elites to pursue a 
developmental state strategy (Doner, Ritchie and Slater, 2005). They refer to this combination of factors as 'systemic vulnerability'. Their argument is forcefully made and highlights in many ways the very particular historical convergences that surrounded the advent of developmental states. They are clear, however, that they are stating their argument so deterministically that it invites falsification (Doner, Ritchie and Slater 2005, p.330). Whilst here is not the place to conduct a full critique of this article, I would like to raise some queries about this highly thought provoking but very deterministic model. The first developmental states involved considerable capital investment from the state in businesses, infrastructure, and education - yet the concept of systemic vulnerability is based on the absence of resources that can be used for rents. I acknowledge that the purpose of the developmental response is precisely to produce resources through developing the economy, but there has to be some initial investment. There are also questions about how long this condition of systemic vulnerability has to be in place, does it just serve to initiate states starting down a developmental state route? Finally, and perhaps most problematically, the criteria, whilst presented as objective, are actually highly subjective (as the perception of credible 'threat' often is).

Threats to the nation and to the government do, however, provide more volatile fluid situations which offer the opportunity for new coalitions, agreements and political settlements to emerge. Perhaps they can also provide an atmosphere in which nationalistic sentiment and commitment to a broader project can emerge. This commitment is seen often as a vital element of developmental states and discussed in the 'National Project /Legitimacy based on developmental outcomes section' below.

\section{Agricultural policies and land reform}

Kees van Donge, Henley, and Lewis' recent comparative work on sub-Saharan Africa and East Asia makes a convincing case for the significance of agricultural reform prior to states emerging as industrialising developmental states (2009). They argue that in South East Asia;

"Agricultural and rural policies raised rural incomes and levels of well-being,

leading directly to mass poverty reduction, and indirectly to the creation of a conducive climate for industrial development" (Kees van Donge, Henley, and Lewis 2009, p.7).

These were not instituted in sub-Saharan Africa where countries spend relatively little on pro-poor, pro-rural policies and thus can be seen as both the root of South East Asia's success and Sub-Saharan Africa's failure. One of the elements which they suggest may have been significant in South East Asia undertaking pro-poor rural policies whilst subSaharan Africa does not is the perception of a more imminent threat of rural rebellion in South East Asia (Kees van Donge, Henley, and Lewis 2009, p.13; Henley undated). This, of course, echoes Doner, Ritchie and Slater's concern with threats of unrest pushing elites to follow a developmental course of action (Doner, Ritchie and Slater, 2005). Kees van Donge, Henley, and Lewis emphasise, however, that these agricultural policies must be accompanied by macro-economic stability (2009, p.7-9). In a more recent paper coming out of the same Tracking Development Project, Henley argues that one of the reasons that these agricultural policies and an agricultural focus was so significant is due to the fact that the policies adopted in East Asia (he takes his examples in particular from Indonesia, Malyasia and also Viet Nam) reached large numbers of people (Henley undated, p.2). As the paper discusses Kenya's less successful agricultural development were centred on a more elitist schemes which focused on 'progressive farmers' and disregarded the majority (Henley undated, p. 5). Evans draws on work on the South African case to argue that disspossession from the land of the African population lead to reduced incomes and a development failure because of the lack of ability for Africans to then utilise "hybrid rural urban family strategies"(Evans 2011, p.39). It is then not soley something inherently special 
about agricultural development but its broadbased approach and abilitiy for families to have diverse livlihood strategies which can be seen to be important.

Evans highlights the absence of dipossession as an element of the East Asian experience (Evans 2011, p.46). In fact rather than dissposession, land reform has been seen to be a significant precursor to the emergence of the developemental state. Korea, Japan and Taiwan all underwent significant land reform (Kuznets, 1988). Whilst most scholars do not posit that agricultural policies and land reform are a sufficient condition for a developmental state to emerge, they are often argued to be a necessary precursor to the emergence of a developmental state. Wade cites Taiwan's land reform as one of the largest non-communist land reforms (Wade 1990, p. 241). Wade sees land reform and a ceiling on land ownership as significant as it limits wealth accumulation in land and improves agricultural productivitiy. $\mathrm{He}$ argues not only that land reform is advantageous, but also that an ongoing cap on land ownership is required to prelong these benefits (Wade 1990, p.297). Land reform can be a signifcant part of an environment which provide economic freedoms to small scale entrepreneurs and peasant farmers, the factor which Kees van Donge, Henley, and Lewis see as vital to the economic successes of South Asia (2009).

The absence of disspossession and land reform are elements in many senses of a weakening or a removal of agricultural elites. The class relations and the relations of the smaller agricultural producers to the state which occurs in the absence of, or political weakness of, these elites may in many senses be what creates developmental outcomes and possibilities. The significance of the reorganisation of agriculture through pro-poor policies, land reform or both can then be seen to be important factors not only because of the impacts that can be seen where they have occured, but also where they have not. Peter Evans argues that India's state has a relatively Weberian bureaucracy but struggles to be developmental and build close relationships with business because of the sizable influence of the large landed rural elites (Evans 1995, p.67-8). Nor did Brazil, the other intermediary state he examines, sweep "reactionary rural elites" from the stage as had occured in East Asia (Evans 1995, p.62). The existance of agricutlural elites per se does not mean that a close relationship with industrialisers and pro-poor rural policies cannot take place. As Evans identifies, India struggles to implement these policies due to its state-society relations along with its hetrogenitiy and sheer size (Evans 1995, p. 66-69). Mauritus did not get rid of its large sugar estates and the elites asssociated with them. However, the state was able to enact policies that went against the interests of this elite and were in many senses pro-poor rural policies. The epitome of this was the sugar tax which was "applied most harshly to the large estates, while small cane growers were assisted and subsidised by the state" (Meisenhelder 1997, p.284). Meisenhelder argues that this was only possible due to the autonomy of the bureaucracy in Mauritius (1997, p.283). An autonomous bureaucracy is a factor which has been seen to be a vital aspect of the developmental state and it is to these that we now turn.

\section{Vital aspects}

The elements discussed below are often seen as necessary for the emergence of a developmental state, and also to form key attributes of a developmental state.

\section{Capable bureaucracy and embedded autonomy}

Peter Evans analysis of what he calls 'embedded autonomy', as well as Chalmers Johnson's 'Japanese model' have been particularly influential (Evans 1995; Johnson 1982; 1987). The first two elements of Johnson's Japanese model and Evans concept of embedded autonomy 
both propose that that developmental state's achievements required a meritocratic rationalised bureaucracy, which can operate autonomously from the pressures of society (Johnson 1982, pp.315-317; Evans 1995). The professionalism of the bureaucracy and its protection from being too buffeted by arbitrary political breezes seems to be an element that is present in the majority of developmental states including those outside of the core East Asian developmental state group such as Botswana (Meyns 2010; Taylor 2005). It is not just a professional autonomous bureaucracy which is required however it also has to be embedded. Johnson and Evans both emphasise that these bureaucracies still need to be connected to their societies and particularly their business communities, to achieve growth (Johnson 1987; Evans 1995 and 1998). Evans term embedded autonomy describes this double move of the bureaucracy not being adversely influenced by interest groups but remaining connected enough to society in order to act to ensure growth and (to an extent) redistribution. This embedded autonomy is seen not only to be a condition which enables the emergence of developmental states but rather it is seen by many to be one of the factors which necessarily has to be present for a state to be considered developmental (Evans 1995 p.12)

Bureaucratic autonomy is seen as important as it is viewed as a key element of what has made these bureaucracies effective (Musamba 2010, p.23). The effectiveness of the bureaucracy is vital for a developmental state as it allows bureaucrats to manage the economy, through the careful selection of key industrial sectors to support and the use of policy instruments to achieve this. In short the bureaucracy needs to effectively reward some businesses and punish others in a way that works to achieve growth (Wade, 1990; Chang 2006; cf.Lockwood 2005, p.117-8). This meant that these bureaucrats had to be insulated in some ways from public and political pressures in order that their rewarding and disciplining could remain un-swayed by political and sectional concerns.

This insulation from political demands for some scholars also involved a degree of autonomy from the influence of ruling politicians. Johnson's analysis of Japan was one of the first to identify the scope for initiative within the bureaucracy and often saw the importance of politicians to lie in fending off of interest group pressures to allow civil servants to manage the economy and industrialisation (Johnson 1982). In Johnson's account bureaucrats are the central agents, and politicians act only to buffer these managers from external demands (Johnson 1982, p.315), in his now infamous formulation politicians reign but bureaucrats rule. However, there is debate about how autonomous or embedded bureaucracies in developmental states have been from politicians and about who exactly has done the ruling. There have been a number of revisionist accounts of Japan which challenge this assertion of bureaucratic insulation and politicians' marginal role (Moon and Prasad 1994, p.367). For example counter to Johnson, Ramseyer and Rosenbluth (1993) argue that Japanese politicians had a high degree of influence over bureaucrats' behaviour. Bureaucratic autonomy has been seen as one of the key benefits of an authoritarian regime, as it is contended that bureaucrats under authoritarianism can be more effectively insulated from societal and political pressures (Wade 1990, p.375). However, Haggard argues that, "It is even misleading to think that bureaucrats enjoyed independence in the authoritarian regimes" (Haggard 2004, p.64). Moon and Prasad for example, contend that Korean bureaucrats were in fact highly dependent upon and vulnerable to the wishes of President Park (Moon and Prasad 1994, p.365). However, this may not indicate the absence of a kind of autonomy, it is just that 'autonomy' should not be seen as disconnection, even within a bureaucracy enjoying high degrees of autonomy the vision and direction that is pursued by bureaucrats is most likely to come from or be highly influenced from the outside (Randall 2007, pp. 638-9). The degree of autonomy which the bureaucracy in developmental states enjoys is then a matter of contention rather than agreement, whilst many continue to see the autonomy of the bureaucracy as significant. 
Whilst discussions of embedded autonomy have often focused on the autonomous aspects and the production of a bureaucracy which resembles the Weberian ideal (Musamba 2010, p.23), the embedded aspect of Evan's concept should not be forgotten. Evans highlights how in Johnson's account of the MITI in Japan bureaucrats were selected in a meritocratic manner, had long term career paths and operated in line with a culture of implementing and following rules in a way that fits with Weber's bureaucratic ideal $(1995$, p.48). Yet there were also significant informal elements that went 'beyond Weberian bureaucracy', but were vital for the competence and functioning of MITI (Evans 1995, p.49). The manner in which bureaucracies are embedded is however significant as these ties which embedded MITI reinforced the bureaucracy, in the main argues Evans due to the cohesiveness and capacity that the bureaucracy already held $(1995$, p.50). How this cohesiveness is developed and maintained is for Evans often through collegial links amongst civil service staff developed at schools and universities and a sense of professionalism (Evans, 1995). This cohesiveness is significant it is not hard to find examples of different contexts where cohesiveness or capacity of bureaucratic institutions is lacking and institutions suffer capture rather than gain increased competence from similar interactions with significant entrepreneurs.

The benevolence of these interactions between business and government in one context and the malign dysfunction of similar close ties in other contexts remains in many senses an unsolved puzzle (Moon and Prasad 1994, p.375). Whilst Evan's ideas of cohesiveness and capacity as part of the reasons why capture doesn't occur are important, they perhaps raise as many questions as they answer and highlight the important contextual elements of embedded autonomy For Evans the manner in which autonomy and embeddedness combine is a product of "both the historically determined character of the state apparatus and the nature of the social structure"(1995, p. 50). How autonomy and embeddedness interact can therefore be seen to vary in different contexts, but also over time. Johnson's work on the MITI provides an analysis of when politicians, business and indeed other external pressures affected or failed to impact the MITI bureaucrats and conversely when MITI was able to effectively alter their actions. It highlights that the relationship between autonomy and embeddedness is one which is constantly under negotiation as bureaucrats, politicians, businesspeople and citizens negotiate the relationship between the state, business and the market. Evans has made a strong argument that for a state to be developmental it needs this autonomous but embedded bureaucrats but this remains an area of contestation rather than a fixed outcome.

\section{National project /legitimacy based on developmental outcomes}

Haggard has identified a tendency for the capacity but not the motivations of developmental states to be analysed and considered (Haggard 2004, p.70). There has then (to borrow Vu's categories again) been more attention paid to what produces developmental systems rather than what inspires states to use these systems to perform developmental roles. $\mathrm{Vu}$ has argued that the Rhee regime in South Korea developed these systems without using them for developmental ends, but the existence of these systems allowed the Park government to undertake developmental roles (2007, p.38). Developmental systems can therefore be in place but not be used for developmental ends, which begs the question what are the conditions under which these systems come to be used for developmental ends?

This does not mean that the significance of the vision or project of developmental states has not been acknowledged. The National government, elite and popular commitment to a national project or vision focused growth and improvement in living standards is regularly cited as a key feature of developmental states (Wade 1990, p.7; Fritz and Menocal 2007, p.534; Lin and Monga 2011, p.278). Johnson argues that the developmental state rests on a kind of revolutionary legitimacy (Johnson, 1999). This has also been called a hegemonic project by Pempel (1999, p.171). It is the mobilisation of the population to make sacrifices to 
achieve developmental ends which Johnson identifies as the key advantage an authoritarian regime has over a democratic one in terms of its developmental potential (Johnson 1999, p.52). This commitment to a developmental vision is a part of the definition of a developmental state for some (Fritz and Menocal 2007, p.533) - although the other part of this definition is their capability to make progress towards this vision. Thus, whilst this commitment and drive is vital to the emergence of a developmental state it is also in some senses the outcome of a developmental state. This popular and elite mobilisation towards a particular end translates into the mode of legitimacy of the developmental state. Whilst, as has been discussed elsewhere, civil society is to some extent sidelined and many developmental states have drawn their legitimacy from their achievements in terms of growth and in particular improvements in living standards (Leftwich 2008, p.16; Johnson 1987, p.143; 1999, pp.52-53; Wade 1990, p.298).

Developmental vision and drive in the contexts most frequently discussed as developmental, namely the core East Asian states, have often taken on a nationalistic tone (Woo-Cumings, 1999). Nationalism served not only as 'rallying cry' to mobilise action. The national developmental project provided a sense of social cohesion an awareness of "we're all in the same boat" (Pempel 1999, p.168-9). However the pre-existing feeling of relative social homogeneity within these particular countries assisted in this,

"In Japan, Korea and Taiwan, however, little question exists about the bonds of nationhood, making it much easier for governments and individual businesses to adopt principles of individual, meritocratic mobility." (Pempel 1999, p.168)

As this quote from Pempel shows this social cohesiveness also facilitated the social mobility and wealth redistribution which were also key features developmental states. ). Johnson sees "policies to ensure the equitable distribution of wealth created by highs-speed growth" to be part of what he calls the model of East Asian high-growth systems (Johnson 1987, p.145). It also shows the significance of social homogeneity for developmental states and perhaps raises issues about the transferability of some of these gains to countries in which ethnic, religious or other divisions would make the perception of social homogeneity and feeling of 'we're all in the same boat' less likely.

\section{Developmental Political Settlement}

Closely related to elite commitment to the developmental state, one of the most widely agreed upon elements that is seen to be essential to the formation of developmental states is the production of development agreements and/or coalitions (Leftwich 2010, pp.101-2)

"All governments in the region reached explicit or implicit political agreements with segments of the private sector; these agreements or coalitions served as the political foundation for rapid growth" (Haggard 2004, p.71)

These can be thought of as each country's political settlement. Political settlements are understood to be a central core around which elites agree; they constitute to borrow Adrian Leftwich's phrase the 'rules of the game'. (Leftwich 2008) They are not unchanging, but neither do they constitute the rapidly changing content of politics rather they are seen to form the framework through which these contestations play out. The developmental state could therefore be seen to be built upon particular kinds of political settlements, which have a developmental vision at their core. This consensus and the political settlement forms, the foundation for and the essential character of the developmental vision discussed above.

The political settlements literature concerns itself in part with how elites come to form coalitions and agree upon these political settlements. What within the context of the developmental state the elite coalitions, associated with political settlements, can in particular be seen to exist between business and bureaucratic elites. These relations are discussed in more detail under the section on business-state relations below. However, the 
nature of the political coalition which enables the state to pursue a developmental path is contested within the literature. In particular, scholars debate how broad or inclusive it is useful for this coalition to be within the context of a developmental state. Doner et al. argue that the necessity of maintaining a broad coalition is part of the set of pressures which make states take up a developmental path as it requires them to upgrade their economy. (2005, p. 331) This upgrading is vital in order to maintain growth levels that make the broad coalition affordable.

Similarly Poteete writing on Botswana contends:

"Politicians with broader and more stable coalitions are less likely to turn to rentier politics to bolster support, in part because they are more apt to believe that they will recap the benefits from investments in state building." (2009, p.545)

However, Wade argues that a narrow coalition is preferable, for a developmental state, as it allows for greater insulation of the bureaucracy - it is the narrowness of the coalition which he sees as an advantageous element of authoritarian states. (Wade 1990, p. 375) Wade's view is in line with Vu's observations of Korea and Indonesia. Vu argues that Korea's narrow, oppressive, leading coalition had the ability to be more effective than Indonesia's inclusive but fragile broad coalition. (Vu, 2007)

Wade, drawing on Douglas North's work, sees all of the East Asian developmental states to have been 'limited access social orders'. (Wade 2010, p.157)

"Elites in limited access orders use rents to maintain order and to hold the social order together. The political system manipulates the economy to generate rents that bind the interests of economic actors to support the current political system." (North et al, 2007, p.6)

In some senses then Wade's contention that the East Asian developmental states were regulated by limited access orders intersects with debates around the role of rents and corruption within developmental states which are addressed in more detail below. However it also highlights the discriminatory nature of the narrow coalition. Discriminatory in as much as it is specific social groups - industrial capitalists - who have a close relationship with the state to the exclusion of other groups.

This limitation in state society relations has been discussed as the weakness of civil society within developmental states (Leftwich 2000, pp.163-4; Hayashi 2010, p.57). One observation which arises out of this is that a political settlement can be inclusive, in terms of its egalitarian outcomes - which are frequently attributed to developmental states - even if it is exclusionary rather than pluralist (Di John and Putzel 2009, p.5).

\section{Business-State Relations and Industrial Policy}

State business relations have been a key part of the developmental state story and a key part of their success. For Chalmers Johnson and many other scholars one of the key defining elements of the developmental states are their particular configuration of its relationship between state and society. Johnson talks of America as a regulatory state which seeks to regulate the actions of business in contrast to Japans developmental state which has a much more engaged mode of operation, in short it is this very different statebusiness relationship which marks them as developmental (Johnson, 1982; Johnson 1999, p.37). State business relations are of course part of a broader set of relationships between the state and society. However, the close ties of business and government are often in many senses exclusionary and discriminating in that they build close networks of 
relationships with some groups and exclude or even forcibly marginalise others. Labour and civil society have often been the groups who are weak, excluded or suppressed (Vu, 2007; Leftwich 2000, pp.163-4; Pempel 1999, p.166; Johnson 1987 pp. 149-151, Hayashi 2010, pp.57-8), whereas industrial leaders have been drawn close to the point where some have argued that they become a single internal organisation (Moon and Prasad, 1994, p. 374). As Evans argues the developmental states form of embedded autonomy was replete with dense links with industrial capital and "from the point of view of other social groups it was an exclusionary arrangement" (Evans 1995, p.17).

The close relationship between business-people and bureaucrats has been a vital aspect of the state's ability to control and co-ordinate the private sector with an aim to achieving growth (Moon and Prasad 1994, p.363). One of the key elements of the relationship between the state and industrialists was the capital (often as credit) that the state had available which it could use to selectively invest in sectors strategically in a capital scarce environment (Evans 1995, p.53; Hayashi 2010, p.62). These financial ties were accompanied by the development of close relationships between ministries and major industrialists (Evans, 1995, p.49). Centrally these state-business relationships were about the pursuit of growth in a way that was considered by both parties beneficial for both business and the state what Bräutigam, Rakner and Taylor call 'growth coalitions' (2002). Their work on state-business interactions in Mauritius, Zimbabwe and Zambia argues that these growth coalitions can and have emerged in sub-Saharan Africa but that they are difficult to sustain because the building of the belief in the mutual benefit of the coalition is complicated by "aspects of race, class, and ethnicity" (Bräutigam, Rakner and Taylor 2002, p.540). Their argument echoes Pempel's argument about the benefits that the core developmental state drew from their perceived relative social homogeneity, discussed above.

There can be substantial synergies for growth coalitions but the partnership between business and the state needs to remain balanced (Wade 2010, p.158). Evans' associates an unbalanced state-business relationship with what he calls intermediate states. He sees these imbalances as leading to "...excessive clientelism or an inability to construct joint projects with potential industry elites. Inconsistency is another possibility" (Evans 1995, p.60). Close relationships between state and business do not then in themselves necessarily have positive developmental outcomes. Wade cites the Philipines as a negative example of penetration or capture of the state by business interests (Wade 2010, p.158). Meisenhelder also argues that in the case of Mauritius one of the vital elements which allowed the state to take a developmental course was the independence of the bureaucracy from the dominant economic class (although this was a landed agricultural elite).

Bureaucratic autonomy, state capacity and close state-business relationships are not purely ends in themselves. Rather within the developmental state context they are crucial elements which enable the state to devise and implement market conforming industrial policies; so they can in Wade's terminology 'govern the market' (Wade, 1990; Johnson 1982; Sandbrook, 2005; Evans, 1995). There is a good case made for the central importance of industrial policy for states wishing to industrialise (Lin and Monga, 2011). Wade highlights that whilst it is difficult to disentangle the impact of the industrial policies followed by the core East Asian states from other factors but that detailed accounts of how these policies worked indicate that these policies were effective (Wade, 2010, p.155; 1990; Amsden, 2001). Although as Moon and Prasad point out there were also failures (1994, p,369). One of the key features of the relationships between bureaucrats and industrialists was that industrial policy was used in a disciplining manner to reward success (Wade 2010, 1990). This ensures that the interventions undertaken by developmental states are 'market conforming' (Johnson 1982; Johnson 1987) and effective in producing growth. 


\section{What about 'new' developmental states?}

\section{What lessons should be learnt from the East Asian experience?}

East Asian developmental states' impressive and relatively sustained growth records have led to an interest in the transferability of this mode of governance to other developing 'countries. Despite the tradeoffs that developmental states involve that Vu highlights and posits that "the experience of developmental states may not be worth emulating" (2007, p.49), there has been a concerted concern with what can be learnt from the East Asian experience (Wade, 1990; Evans, 1998; Williams et al. 2011; Hayashi, 2010). However, given the vast array of interpretations of what factors were the most influential in producing developmental states what lessons are to be transferred remains highly contested. Most scholars exploring the possibility of transferring the developmental state model do not see the transfer as a straight forward process. Moreover, many scholars contest the transferability of institutions and practices from developmental states to other states and "...the relevance of the East Asian 'developmental state' model for countries in Africa and elsewhere" (Williams et al. 2011, p.340). This section briefly explores some of the issues around implementing the 'lessons' of the East Asian and especially the North East Asian experience elsewhere.

\section{The (im)possibility of transferring the developmental state model to Africa and elsewhere}

In debates around the transfer of the East Asian developmental state model to other regions it seems that the transfer of this model to Africa has generated the most debate within the literature. There has been dissent around the possibilities for the emergence of developmental states in Africa with some exposing what Musamba entitles the 'impossibility theorem' arguing that African states will not be able to become developmental (Musamba 2010, pp.30-31). Thandika Mkandawire's 2001 article is in essence a refutation of this overtly sceptical view of the possibilities for African states to be developmental.

In his introduction Mkandawire highlights the central disjuncture within the literature on African states regards the developmental state,

"States whose capacity to pursue any national project is denied at one level (theoretical or diagnostic) are extorted, at the prescriptive level, to assume roles that are, ex definicione, [by definition] beyond their capacity, character or political will." (Mkandawire 2001, p.289)

This is the central contention according to Mkandawire of much of the literature on the state in Africa, and this characterisation of the literature is not without foundation as much of the literature concerns understanding African states as weak, predatory or kleptocratic. (Jackson and Rosberg 1982; Bayart, Ellis and Hibou 1999; Diamond 2008) He argues that the replication of East Asian successes are seen by other scholars as impossible because of how the African state is viewed as well as other elements such as the international environment. (Mkandawire 2001, 294) Mkandawire rejects that these various characterisations of the African state, and the inability of African states to be developmental pointing to the diversity of African experiences and arguing against the assumptions made within these portraits of African states. Musamba makes similar arguments drawing on Mkandawire's work to highlight the possibilities for developmental states to emerge in Africa. She highlights in particular (in line with some of the discussion above) the importance of the adaptation of the developmental state model to the African context (Musamba 2010, pp.34 35). 
Mkandawire and Musamba's rejection of the wholesale denial of the possibility of developmental states emerging in Africa deserves to be taken seriously. However, many of the issues and barriers to the emergence of developmental states in Africa and elsewhere also have considerable purchase. Musamba outlines several arguments of those who espouse the impossibility theorem (2010, pp.30-33). Drawing on her summation, my own categorisation is that there are three key substantial strands to the arguments made about the difficulties of the transferral of the developmental state model.

1. The changed geo-political situation (from when East Asian states became developmental) and increased globalisation.

2. The generic problematic nature of the transfer of institutions.

3. The absence of state capacity and developmental commitment in Africa and elsewhere.

I will not explore the first strand about the changed global economic environment here as the next section deals with this in detail. The third strand I think commits the error of saying that developmental states cannot emerge as they are not currently emerging. As state capacity and commitment are what defines a developmental state saying that they are absent does not mean that they will not be present in the future - of course these processes take time. There are also of course states in Africa and elsewhere that do show promise of state capacity and commitment; Lockwood highlights Tanzania (Lockwood 2005) and others have highlighted Ethiopia and Rwanda

The second strand about the generic problematic of transferring institutions from one context to another and the specificity of the East Asian experience is however highly relevant and has been part of the discussion surrounding developmental states from when the term was coined. Chalmers Johnson was one of the first to layout the character of what he called 'the Japanese model' and identify abstract features which other societies could use as a guide (1982, pp.314-5). Interestingly the state which he identified as possibly desiring to learn from Japan's experience was the United States (Johnson 1982, p.323). Despite Johnson's outlining of a Japanese model, he also highlights that the significance of Japan's experience rests on them building on pre-existing 'assets' rather than following dogmatically models which had worked elsewhere (1982, p.322). He argues that;

“... other nations seeking to emulate Japan's achievements might be better advised to fabricate the institutions of their own developmental states from local materials." (Johnson 1982, p.323)

Peter Evans has a similar view that East Asian lessons could produce development elsewhere if "understood as an invitation to indigenous innovation" (Evans 1998, p.79). For Evans it is the ability of East Asia's developmental states to reinvent rather than copy that was vital to their success and possibly a key 'transferable lesson' (Evans 1998). This does not mean that he rejects attempts at transferring the lessons from the East Asian experience, as he sees it as a way to avoid fatalism and hopefully posits,

"In the best of all possible worlds, African and Latin American countries would follow the lessons generated by the East Asian experience in the same way that East Asian policy-makers followed western models of capitalism: with such originality and inventiveness as to outperform the original." (Evans 1998, p. 83).

Adaptation and innovation should then be the hallmark of any emerging developmental state rather than a dogmatic following of the East Asian model. This does not mean however that there are not particular challenges for any developing world state embarking upon an developmental path that were not present for other states when they took a developmental turn. There were specific elements, many of which are laid out above, that were highlight conducive to the emergence of developmental states especially in the East Asian case which contemporary states do not have the advantage of. A number of these are about the altered global economic environment which is dealt with in the next section. 


\section{Changed Global Economic Environment}

"It is highly unlikely that potential emulators of the Northeast Asian political economies will enjoy anything like the same favourable international conditions as did Japan, Korea and Taiwan" (Pempel 1999, p.180).

Global conditions are vitally important for the emergence of developmental states because in many ways the strategies of developmental states are about a change in the position of the state globally and are also tightly tied into international markets; as Evans argues, "[industrial] transformation is inescapably defined in global terms" (Evans 1995, p.6). The possibilities for states to undergo rapid growth and industrialisation are therefore constrained and shaped by the global environment (Beeson 2004, p.31). The changed nature of these international interactions has a significant impact upon the emergence of developmental states. $^{12}$

One of the key changes is globalisation and global economic liberalisation. These put particular pressures on developmental states industrial and economic policies. These pressures were less prevalent when the current successful developmental states started to pursue these policies - although they were not absent. In addition, the east Asian states' significant strategic geopolitical position meant that the US who have subsequently been a key driver behind the pressure to liberalise and open up national markets, in order to level the playing field, were well disposed towards these states and in fact opened up their markets to them. (Chang 2006, p.18; Pempel 1999, p.155). This economic tolerance or support was of course offset for the Americans by the political commitment these states gave to their side in the cold war (Hayashi 2010, p.46). As Beeson states,

"...the tolerant geopolitical environment which saw the US privilege systemic strategic issues over, narrower national economic interests, and which provided the relatively tolerant environment in which the DS [developmental] states flourished, has been overturned" (Beeson 2004, p.32).

This special status in relation to a dominant global power does not apply to new developmental states and the pressure to liberalise has been seen as proposing particular difficulties for states wishing to take a developmental route (Hayashi 2010, p.60; Chang 2006; Wade 2003). Many of the industrial strategies undertaken by developmental states have been protectionist and nationalistic rather than following the neo-liberal free market line. The current global political environment places considerable pressure on countries to liberalise and to open up their markets. Wade has argued that this pressure limits the 'development space', in the options available to developing countries to protect their emerging industries; many of which were utilised by the East Asian developmental states (Wade 2003, p.622). Chang however contends that this argument is sometimes overstated and argues that there is an exaggeration of the amount of policy freedom which existed in the pre-World Trade Organisation international trading system and also that the new WTO "constraints are not as widespread and binding as they are usually made out to be" (Chang 2006, p.51).

\footnotetext{
${ }^{12}$ There is also literature which examines how globalisation and liberalisation is changing existing developmental states, however, there is not space to explore this here but discussions of this topic can be found in Linda Low's edited volume (Low, 2004a).
} 
However, it is not only liberalisation in terms of preventing protectionist industrial policies that impacts newly emerging developmental states, it is also the changed relationships between local and global capital, part of what can be called globalisation. These changed relations place the state in a different position with regards their domestic industrialists who in the East Asian case were reliant on the state in many senses for capital (Evans 1995, p.53; Hayashi 2010, p.62). There has been a weakening globally of states' control over their own national economies through this process of globalisation (Hayashi 2010, p.46). As governing the market (Wade 1990) has been seen to be at the core of the developmental state this poses a significant difficulty for states wishing to emulate previous developmental state practices. As Evans has it,

"The growing power of global capital and the growing integration of local capital

into transnational networks has made close ties with capital riskier and more difficult for a developmental state" (Evans 2011, p.50)

Clearly global capital's influence is increasing, however, Sandbrook et al. argue that globalization brings significant complementarities for developmental states as well as challenges (Sandbrook et al. 2007, p.227). These centre on global capitals requirements which do not always constitute 'a race to the bottom' but which often demonstrate preferences towards states in which services and infrastructure are provided by the state, in which populations are educated and healthy and where the likelihood of disruptive violent unrest is low (Sandbrook et al. 2007, pp. 227-230). However, the increased risks involved for developmental states engaging with capital in a more globalised environment remain, and the social democratic developmental states which Sandbrook et al. study are seen to be exceptions rather than the rule (Sandbrook et al. 2007). ${ }^{13}$ That said these exceptions merit analysis and the explanation which they have provided for their success is not the avoidance of the risks of global capital but the management of them through provision of social protection (Sandbrook et al. 2007, p.230).

Finally alongside the challenges of liberalisation and globalisation newly emerging developmental states face considerably slowed growth in global markets. Markets were expanding at the time Japanese, Korea, Taiwan and Mauritius were successful in upgrading their economies (Wade, 1990, p.346; Meisenhelder, 1997, p.290). Since then this expansion has slowed considerably which will make it harder if not impossible for states to achieve growth using the same strategies that the East Asian states utilised (Wade 1990, pp.347-8; Hayashi 2010, p.59). Although as Wade argues this does not necessarily mean that there are better policies available and that the strategies of developmental states should be jettisoned (1990, p.348). The change in the markets is not just limited to the declining growth of the markets for goods. There are also connected changes in the labour market globally which affect the strategies which will be necessary for emerging developmental states. Manufacturing jobs were decreasing at the end of the $20^{\text {th }}$ century in both the global south and the global north, even in China often seen as the current hub of manufacturing production (Evans 2011, p. 41). The growing sector of the labour market is the service sector, which requires different types of inputs - centrally argues Evans they require human capabilities (Evans 2010; 2011). This in turn requires a developmental state which looks quite different to its East Asian precursors - the possibilities for different routes to a developmental state are discussed below.

\section{What forms of governance? (Authoritarianism? Democracy?)}

Whilst transferring the economic growth and poverty reduction gains of developmental states to other parts of the world is generally seen as laudable if practically difficult, there are also

\footnotetext{
${ }^{13}$ The cases of social democracy in the global periphery that they examine are Kerala, Costa Rica, Mauritius and Chile.
} 
problematic elements of developmental states which have often been authoritarian rather than democratic. (Fritz and Menocal 2007, p.536) This raises debates around the relationship between democracy and the particular state-society relations constructed within developmental regimes. As we have seen from Evans concept of embedded autonomy there is a need for the bureaucracy to be shielded from demands of society for it to be autonomous. Democracy in itself has been seen as problematic for the emergence of developmental states due, to the short-termism that electoral politics can breed, as opposed to the long view that those pursuing a developmental vision in developmental states can take (Kelsall and Booth 2010, p.27). Although as Sandbrook et al argue; "It is disputable that authoritarian governments are any less prone to instability and unpredictability than democratic ones" (2007, p.23). This is often seen to conflict with the frequent calls of western donors for accountability and democracy - often discussed as good governance. There is then, much debate within the literature on the possibilities for, and existence of, democratic developmental states. The anti-democratic nature of many developmental states is seen by some scholars to be problematic in-and-of-itself, or in regards to specific issues such as - environmental justice. (Neo, 2007)

The importance of the nature of the regime (authoritarian or democratic) for the emergence of developmental states has been one of the key debates within the developmental states literature. In part this is because democratisation has been a key plank of western development policy and the developmental properties of authoritarianism is thus a significant challenge to this stance. As long ago as 1998 Gordon White highlighted that there was no longer a consensus on the positive developmental properties of democratisation (White 1998, p.5). This shift was in part due to the successes of the East-Asian authoritarian developmental states. A number of factors have been posited to constitute a positive linkage between authoritarianism and the emergence of developmental states. An authoritarian government is seen to be able to take a longer term view (Johnson 1987, p.143). The state is also able to suppress, or ignore, interest groups demands which allows for the necessary bureaucratic autonomy (Wade 1990, p. 375).

Authoritarianism is not however seen by scholars as necessarily being developmental (White 1998, p.7; Fritz and Menocal 2007, p.536). Vu argues that the suppression of the masses, as opposed to their incorporation, allows for the construction of a developmental structure (2007, p.30). But all authoritarian states do not build this developmental structure (Vu 2007, p.49). The linkage between regime type - democracy or authoritarianism - and growth generally seems to be weak (Haggard 2004, p.59). However, this does not explain the clustering of developmental authoritarian regimes in East-Asia (Haggard 2004, p.60). The problem with this argument may be as $\mathrm{Vu}$ identifies that Authoritarianism (and indeed democracy) are too broader terms which encompass a vast range possible sets of state society relations (2007, p.48).

The literature which discusses the emergence of new developmental states - particularly in Africa - has however argued that they are likely to be democratic. This is in part because as White has argued the majority of states are now democratic (White 1998). However, it is also an aspiration with many advising that this is what would bring about the 'best' developmental outcomes (Edigheji, 2005; Musamba 2010). There are of course already democratic developmental states significantly Japan and Botswana. Democracy may however change the nature of developmental states by requiring a broader based coalition as in Botswana (Poteete, 2009) rather than the narrower one in South Korea (Vu, 2007). After all Evans argues that it was a fairly narrow group of bureaucrats and industrialists with whom the dense links of embeddedness were formed in the east Asian developmental state cases he looks at. However, he also looks at case studies in India and Austria and suggests that, 
"...a broadly defined embeddedness may offer a more robust basis for transformation in the long run. This suggestive evidence argues for further exploration of potential variations of embedded autonomy" (Evans 1995, p.17).

So for Evans broader incorporation of social groups such as labour and other civil society interests under a democracy may in fact be possible and desirable in newly emergent developmental states.

Evans has recently developed these ideas in a recent chapter and paper, where he argues that the $21^{\text {st }}$ century developmental state will in contrast to its $20^{\text {th }}$ century version need to build close ties and be embedded in a broad cross section of society (Evans 2010; 2011). This is because he sees the $21^{\text {st }}$ century developmental state as centrally being a capability enhancing state, looking to promote the capabilities of their citizenry through provision of collective goods such as, health and education (Evans 2010; 2011). He does not see this as a complete departure from the developmental state model of the East Asian states and highlights the high levels of investment in education (Evans 2010, p. 5; Evans 2011; p.47). However, the focus on the development of capabilities means that the 'knowledge' required by the state cannot be obtained only by building the close ties that Evans and other documented between business leaders and the bureaucracy in the East Asian case (Evans, 1995; Moon and Prassad 1994). Instead there will be an acute need for "information on collective priorities at the community level" (Evans 2011, p.49). This requires that policies are not created by technocrats rather Evans argues they "must be derived from democratically organised public deliberation" (Evans 2011, p.43).

\section{What type of bureaucracy?}

State capacity and the effectiveness of the state, in that it is able to act and attain significant progress towards most of its goals, continues to be an essential foundational element of developmental states (Evans 2010, p.3). The establishment of effective states, generally with high levels of bureaucratic capacity, is seen as a prerequisite for the development of a developmental state (Leftwich 2008, p.4). The nature of the bureaucracy as has been discussed is seen to be vital for the emergence of a developmental state. The bureaucracies of developmental states are generally seen to be in a number of ways close to the Weberian ideal. Their staffing is seen to be significant. The civil service in a developmental state is usually seen to be: recruited along meritocratic grounds from top universities; possess prestige as a career; have clear merit based promotion prospects; and have a sense of internal cooperate coherence (Johnson, 1982; Evans, 1995). However, Evans cautions against assuming that a 'super bureaucracy' staffed by 'incorruptible superbureaucrats' are needed for developing states to move towards becoming developmental states (1998, p. 79). He argues that whilst there does need to be more than 'pockets of efficiency' (which in earlier work he identified as present in Brazil (Evans 1995, p.61)), minimal norms of probity and competence" will suffice in general and radical transformation of bureaucratic practice can be reserved for agencies key to economic policy and planning (Evans 1998, p.79-80).

The nature of the bureaucracy required may also vary in future developmental states as they may be required to undertake quite different roles to those required of the East Asian developmental state bureaucrats. Evans has recently argued the $21^{\text {st }}$ century developmental state will need to be a capability-enhancing state. The role of the bureaucracy in this conception of the developmental state is quite different. One of the key roles of the state, in this model, is to facilitate the co-production of capability-enhancing services through building links with civil society actors which allow for a consensus about the provision of collective goods such as education and health to be researched (Evans 2011, p.49). The skills and dispositions required for these kinds of activities are very different to those needed by East Asian bureaucrats who manipulated industrial policy in order to 
promote growth. However the bureaucracy still requires a high level of competency, state capacity and effectiveness are essential to the success of a $21^{\text {st }}$ century developmental state. In fact more competence is likely to be required due to the higher levels of direct involvement and provision involved in this model (Evans 2010, p.7).

Within the literature there seems to be some consensus that if developmental states emerge in the near future these will look remarkably different to the states originally labelled as developmental. How useful labelling states as developmental states in contexts where these states cannot be said to possess the attributes originally associated with the category remains an open question. There could be perceived gains for states attempting to perform some kinds of developmental roles through the association with states which are seen as 'successful'. On the other hand perhaps tying our debates to the question of what similarities or differences can be perceived from the original developmental state model may in fact blunt our analytical grasp of different patterns of social, political and economic relations. The next section examines analyses of possible routes to developmental outcomes that vary considerably from the general developmental state model.

\section{More than one route to being developmental?}

\section{The Social Developmental State}

As has been shown above there is much dispute over what types of governance etc. are needed for a developmental state. As already mentioned there has been a very heavy focus on economic growth in discussions of developmental states, although, the focus on their role in social as well as economic transformation has been acknowledged (Low 2004a, p.6). However there is a discernible shift in some recent thinking on the developmental state to bring social and political aspects to the centre of the developmental state (Evans 2010; 2011; Sandbrook et al. 2007). The shift in focus is to "people and their skills instead of machines and their owners" (Evans 2010, p.6). This does not necessarily mean that the industrial and economic policy instruments utilised by East Asian developmental states are by any means redundant "many of the same "market-conforming mechanisms" are seen to be employed by the states discussed as social democratic developmental states (Sandbrook et al. 2007, p.24). Evans urging of states to become capability building is also based in part on East Asian states and Chinese investment in education and health which he sees as key to their subsequent success (Evans 2011, p.47). However, the historical examples on which scholars draw for their discussion of these more socially and politically oriented developmental states are not only the East Asian case but also Scandinavian cases in the late $19^{\text {th }}$ early $20^{\text {th }}$ century (Sandbrook et al. 2007).

That the Scandinavian example is drawn on is significant as it focuses discussion of the developmental state away from an examination of what elements caused economic growth to examining a form of state which grew out of a negotiation of how poverty was to be relieved / managed (Sandbrook et al. 2007, p.29). The social democratic developmental state which Sandbrook et al. see as following a the Scandinavian model comes out of negotiating similar issues around building a society without poverty and social exclusion (Sandbrook at al., 2007 p.232). This explains its focus on social protection and redistribution but it is also a negotiation and a compromise that seeks to ameliorate the negative impacts of global capital and the markets without disengaging from them (Sandbrook et al. 2007, pp.232-4). Similarly Evans does not see disengagement from the global market place as the way to produce what he calls a capability expanding state; rather expanding human capabilities (in terms of the provision of health and education services and infrastructure) is not seen solely as a developmental end, it is also a developmental means as it enhances growth in a global employment market place which requires skilled healthy workers (2010; 
2011). This is in agreement with the Sandbrook et al. argument about the complementarities of globalisation in which global capital comes to value the provisions made by the state for health, education and social protection not for themselves but for the benefits they bring to 'doing business' in these states (Sandbrook et al. 2007, pp. 227-230). The focus on social development is not seen therefore to be at odds with growth but rather to compliment it.

Both Sandbrook et al and Evans see an effective state as a key element required for the emergence of a successful social developmental state (Sandbrook et al. 2007, p.236; Evans 2010, p.3). In this respect they echo Vu's requirement for developmental structures (Vu, 2007). Another key element of convergence is the significant role which they ascribe to civil/political society within the state. Evans emphasises democracy and public deliberation as the only way in which the state will be able to fully comprehend the services or infrastructure necessary for it to enhance capacities (Evans 2011, p.43). Sandbrook et al. highlight that the class structure of the state predisposes support for "equitable socially protected development' and facilitates the emergence of multi-class political movements, which in turn produces a vibrant civil society (Sandbrook et al. pp.207-8 and p.236). Civil society, (and in this account civil society is a highly political arena) is the site in which the negotiation of how to manage poverty and the impacts of globalisation and ensure 'equitable development' takes place.

Although this image of the social democratic state in the global periphery seems very different to the mainstream account of developmental state it still requires political will and motivation and state capacity - Vu's structures and roles. However, the circumstance under which the state takes up developmental roles is different and is in many senses a different set of roles. It also reflects the main stream story in terms of the high degrees of innovation which were required to navigate the challenges of being incorporated into global capital whilst ensuring the development that emerges is 'equitable' (Sandbrook et al. 2007, p.254). Evans also sees building a social developmental state as a "continually reflexive, learning by doing process" (Evans 2011, p.37). They are also formed by the particular processes of state formation and class relations as well as by agents taking up key opportunities (Sandbrook et al. p.236 and p.31). The social developmental state could be seen to be of great benefit to many countries but the need for local innovation and adaptation remains as does the dangers of trying to extract a model of it and implement it in other states as Evans says developmental states do not come 'ready to wear' (Evans 2010, p.4).

\section{The patrimonial developmental state}

Interesting analysis has been conducted by the Africa Power and Politics Programme (APP), which brings to light how patrimonial forms of governance can also perhaps be developmental (Kelsall and Booth, 2010). Their work highlights how a patrimonial mode of governance can take different forms, some developmental and some not. They examine a number of case studies of states whose forms of patrimonialism can be seen to have had positive developmental impacts. (Booth and Golooba-Mutebi, 2011; Cammack and Kelsall, 2011; Kelsall and Booth, 2010)

Clientelism and patrimonialism can be seen to be a barrier to becoming developmental. It is a barrier which has been seen to be a particular issue for African states. In his article arguing that developmental states could emerge in Africa Mkandawire argues that a number of the immediate post-colonial African states would qualify as developmental states (Mkandawire 2001, p.291). Musamba whilst broadly supportive of Mkandawire's argument disputes the assertion that these states fitted the developmental state model (Musamba 2010, pp.28-30). She suggests Mkandawire's development focused leaders existed but only in some African states, moreover, even within the states where these leaders predominated the states they headed did not fit the developmental state model due to; excessive statism, a 
lack of an autonomous and efficient bureaucracy, rent seeking undermining performance focused governance, and an absence of regard for the significance of the private sector as part of the route to development (Musamba 2010, pp.29-30). However, recent work on developmental patrimonialism argues that rent seeking, may not always act as a barrier to these states becoming developmental (Kelsall and Booth, 2010).

The departure point for APP's explorations of patrimonial developmentalism is that different types of patrimonial and clientelist behaviours have different types of impacts (Booth 2010, p.7). Kelsall and Booth analyse the forms of rent seeking in a number of states under particular regimes in terms of their centralised or decentralised nature and in terms of their orientation to a long or short-term horizon (2010). They then identify some African regimes namely, Kenya 1965-1975, Malawi 1961-78 and Côte d'Ivoire 1960-75 as 'developmental' in terms of their strong economic performance. (Kelsall, and Booth 2010, p.12). Other factors associated with developmental states can be found in the examples, of 'developmental neopatrimonialism discussed by the APP programme. In particular the importance of the civil service especially in terms of its professionalism and its capacity emerges from some of their work. For example they discuss Kenya's autonomous bureaucracy (Kelsall and Booth 2010, p.19) and also the professionalism of the bureaucracy during the first period of Banda's rule in Malawi (Cammack and Kelsall, 2011). Cammack and Kelsall's description of the civil service in the Malawian case in particular reflects many of the qualities ascribed to the bureaucracy in developmental states. In as much as bureaucrats were highly educated and drawn from prestigious institutions, there was a clear career path, and promotion was based on merit. (Cammack and Kelsall 2011, p.90) Kelsall and Booth do not claim these as simply as fitting the developmental state model either as it is laid out by Johnson as the 'Japanese model' or the defining features of the developmental state identified by Musamba. However, they seem to suggest that maybe developmental patrimonialism is a different way in which a more developmentally focussed state may come about both with the attendant gains of economic growth and social improvements.

One of the key assumptions which some scholars working on APP challenge is that clientelist behaviours and neo-patrimonial regimes automatically undermine bureaucracies (Booth 2010, p.15 \& p.17; See also Williams et al. 2011, p.340). This should perhaps not be that much of a surprise to scholars of developmental states as there was considerable corruption between government and business within Japan, Korea and Taiwan (WooCumings 1999, p.16; Moon and Prasad 1994, p.375). But there is also the assertion that this corruption was not detrimental like the anti-developmental damaging patrimonialism which occurred elsewhere (Hayashi, 2010, p.52). Developmental states however could be seen to be at risk of clientelist capture by the business interests with which they had a high level of linkage, "[South] Korea pushed the limit to which embeddedness could be concentrated in a few ties without degenerating into particularist predation" (Evans 1995, p.53). In a number of the South East Asian states this 'over embeddedness' was discussed as crony capitalism (Putzel, 2002). Clientelist capture is not then completely alien to developmental state regimes, the presence of clienteleism and patronage in other settings cannot therefore simply account for their lack of development. (Kees van Donge, Henley, and Lewis, 2009, p. 5)

What is being described as developmental patrimonial state can be seen in a number of senses to be a different configuration of state society relations. Evans argues that; "Only when embeddedness and autonomy are joined together can a state be called developmental." Perhaps the developmental patrimonial state tips the balance towards embeddedness but still incorporates these two elements, afterall one of the key elements that emerges out of APPs working papers is the importance of a well respected in some senses effective, professional disciplined bureaucracy alongside patrimonial elements 
(Booth 2010, Kelsall and Booth 2010, p.19). In this way perhaps patrimonial developmental states could be seen to be another way of pursuing developmental goals.

There are however problematic elements of patrimonial developmental which rest on the personalised nature of the developmental coalition in many of the examples of developmental patrimonial states. The developmental outcomes are often lost at point of leadership change or in the case of the leader's waning capacities (Cammack and Kelsall 2011). This is perhaps one of the major problematic elements of patrimonial developmental states. As Vu outlines,

"Politicians can consolidate their personal power base differently... For example,

if politicians seek to build a professional network of loyal clients in the bureaucracy, this network helps them but not the state they run. Instead, if they consolidate their power base by building effective coercive state apparatuses, these may stay with the state long after they have left the scene." (Vu 2007, p.36)

In short, the difficulty with patrimonial developmental states is in sustaining the gains made and the absence of institution building.

So do patrimonial developmental states demonstrate another route to development? In some senses they are not as far removed from developmental states, there are a lot of grey areas and overlap. Both corruption and collusion between businesses and the state and the close relationships between bureaucrats and business often vary between the developmental and the developmental patrimonial by degree rather than type. The separation out of the developmental patrimonial state from the developmental state is perhaps not such a clean cut. Additionally, whilst developmental gains have been made by those states highlighted by APP as examples of the model, these successes have not amounted to the miraculous growth of the East Asian economic miracle. So the route can be argued to be not that different nor that successful. Yet there are a number of reasons why this approach is helpful. I will just mention three: Firstly, it examines existing regimes which have achieved some developmental outcomes and tries to understand how this has been achieved. Secondly it pulls apart the complexities of rent seeking and clientelist behaviours rather than treating them all as anti-developmental. Finally, and most pertinently to this review, it offers a way of focusing on developmental outcomes that emerge out of states which do not match the developmental state model. This is valuable as the prospects for new developmental states cast in the East Asian mould are poor, so other approaches adaptations and innovations both in how we understand states as developmental and in how states work towards development are welcome.

\section{Limitations and issues}

This section raises some general issues and highlights some limitations of the developmental states literature.

\section{Agency and structure}

Structural explanations have dominated the developmental states literature. A focus on institutions has been part of this trend and Haggard criticises these approaches for he argues that they obscure politics and social processes (Haggard 2004, p.56). Leftwich identifies an overly structural approach to examinations of developmental states which have neglected to analyse individuals' actions and agency (Leftwich 2010, p.94). He sees this absence as being most fruitfully filled by a focus on the negotiations between elites and the formation of coalitions. This concern with the structures however obscures more than the machinations of coalition building - as important as this process is. It also obscures the 
contingent nature of the state taking up developmental roles and the complex processes by which those in positions to undertaken these roles. These are often taken up as part of a 'national project' - often associated with nationalism (Woo-Cumings; 1999). The analysis of these elements takes us into the rather murky area of trying to understand how nationalist sentiment emerges at particular points. In the case of the core East Asian developmental states, it is likely to be interconnected with the external threats discussed above. However there is a massive literature on nationalism which would serve to offer much more nuanced understandings of the phenomena (See for example: Anderson 2006). In essence what is frequently absent in the literature are explorations and explanations of developmental roles with the building of developmental structures being the focus and the taking up of developmental roles being less frequently explored.

\section{Overly focused on success?}

Some scholars have criticised much of the research on developmental states for being too heavily focused on causal explanations at the expense of fuller accounts of history and context (Woo-Cumings 1999, p.2). Putzel also comments on this dive within the literature on East Asian developmental states criticising it for homogenising their diverse experiences in an attempt to locate the common cause of their success (Putzel, 2002). Haggard goes further and suggests that "the misguided effort to find a single institutional "taproot" for the region's growth" has resulted in problematic analyses which have not been able to account for the variance in the success of policies or the types of institutions which have accompanied this success (2004, p.56).

This offers a caution perhaps to the precipitous transfer of 'lessons'. It also perhaps hints at the need for some of the wider context of countries that wish to become developmental to be considered. This is not to say that outside of the exact context in which Taiwan, South Korea and Japan found themselves developmental states cannot emerge. After all, Botswana's developmental state came about within quite a different context, despite some commonalities between the East Asian Developmental states and Botswana. (Poteete, 2009). However, there is in the literature often overt and perhaps an overly eager focus on extracting the East Asian lesson in part to draw conclusions form it that can lead to policies which will replicate it. Focus on the 'East Asian developmental states' as a homogeneous group that can supply a model means that fuller contextual accounts can be missed, but it can also miss other valuable lessons by honing in on success. This, preoccupation with 'successes' can, according to Moon and Prasad, give an incomplete picture (1994, p.376). Woo-Cumings observes that there have been distinct peaks of research on developmental states when they are prosperous (1999, p.2). In addition Hayashi argues that the intense focus on the 'stellar' successes of the North East Asian States (Japan, South Korea and Taiwan) has obscured the gains of South East Asian states (Thailand, Malaysia and Indonesia) whose experience he contends may actually offer more lessons to other developing countries than those of North East Asian states (Hayashi, 2010). Whilst the focus on success is perhaps understandable it does tend to narrow the focus in a way that can distort the fuller picture and miss some elements entirely from the frame.

\section{The Developmental State as a 'buzzword': all things to all people}

What is the developmental state? I started this review of the literature with an explanation of the term - which emerges out of the literature. However particularly when it comes to discussions of transfer to other states and what lessons are or are not transferred then the question arises of 'when is a developmental state not a developmental state?'. Different scholars put emphasis on different elements of the developmental state, in this review I have tended to utilise the definition which emphasises a state which combines the motives of pursuing developmental ends with the state capacities to do so. I have drawn this from the 
literature but there are alternative interpretations, for example Hayashi's focus on the defining element of a developmental state being state led industrialisation. Neither of these definitions precludes the other however they could be used to define very different states as 'developmental' and they would lead to divergent policy recommendations for states wishing to become 'developmental'.

Despite (or maybe because of this conceptual blurring) the concept of becoming a developmental state has recently become a popular idea for moving forward development in Africa. Within this context the developmental state implies a novel mode achieving development, one which can be seen to empower states rather than international financial institutions. There has been a flurry of conferences and publications on the prospects for developmental states in Africa (Edigheji, 2005; Musamba and Meyns 2010). The ANC in South Africa have already utilised the concept of a developmental state in their electoral campaign material. (Meyns and Musamba 2010), and the Ethiopian Prime Minister Meles Zenawi recently promoted the model as the way forward to African finance ministers (New Business Ethiopia, 2011). Developmental states have been called for by the Economic Commission on Africa, in a manner one journalist described as a mantra,

"As with all such highly general prescriptions, the implementation of this call for "developmental states" is both complex and problematic. And reading this report one feels that repetition of the "developmental state" mantra is likely overdone, as compared with relatively little attention given to the obstacles to the emergence of such states, of which the authors are undoubtedly well aware." (Africa Focus, 2011)

This taking up of the developmental state concept by politicians can be seen as highly positive, but like concepts such as 'good governance', 'participation' and 'poverty reduction', the developmental could also easily become a 'buzzword' - by which I mean a word or phrase which carries so much meaning that its use becomes both meaningless and obtuse and at the same time expected and comforting. The use of the term is not necessarily negative, but it does highlight how the concept of developmental states could become utilised in ways that are un-expected and come to mean different things in different contexts. Harri England has discussed the divergent understandings of Human Rights between the African poor and those working for Human Rights organisations. (Englund, 2006) Similarly Rita Abrahamsen comments on the protests for democratisation in Zambia that for many who participated they were not about 'democracy' but about the socio-economic gains that it was hoped / presumed democracy would bring (Abrahamsen, 2000). In other cases notions such as good governance and anti-corruption campaigns can be used to other ends such as the use of anti-corruption to imprison political opponents (Hall-Mathews, 2007). There is nothing unique about the notion of the developmental state which would mean that its utilisation would not be as divergent - especially considering the diversity of views already present in the literature. This is dangerous in part because the model starts to lose its analytical integrity, but also the label can become appropriated for building structures which are not used to carry out the developmental roles desired (Evans 2011, p.51; Pempel 1999, p.146).

I do not advocate some kind of policing of the definition and usage of the term 'developmental state' as this would be not only futile and bizarre, but also would imply that there is a 'correct' developmental state model. The idea of there being a correct developmental state model to follow brings with it the danger of it becoming the new good governance leading to institutional mono-cropping and rather than adaptation and ingenuity. In raising the prospect of the developmental state as a buzzword I want to highlight that there needs to be some reflection on the usefulness of the concept and care in how it is employed. Not because it does not have analytical purchase in the case of some North East Asian states but because it may not work as a prescribed plan of action for other states, as 
many who have contributed to the development of the term contend (Evans, 1998, Johnson, 1982). An overt focus on the developmental state could close down other possibilities and lead to other developmental possibilities being over looked. It might therefore be more useful to disaggregate elements of the developmental state model and examine elements which the developmental state model highlights as significant (for example the state business relationships and the nature of the bureaucracy) but without measuring these elements in different countries against a new ideal type of the developmental state. There could also usefully be a focus on the central role of adaptability and innovation as part of the core nature of what it means to be a developmental state.

\section{Gaps and an Agenda for Research}

\section{Building with the materials to hand?}

“...other nations seeking to emulate Japan's achievements might be better advised to fabricate the institutions of their own developmental states from local materials" (Johnson 1982, p.323 ).

"One the idea of transferable lessons is understood as an invitation to indigenous innovation that takes advantage of the underlying analytical logic of East Asian institutions, the possibility of exploiting of [sic] the East Asian experience becomes thoroughly possible" (Evans 1998, p.79).

From the beginning of research into developmental states one of the clearest messages was the absence of a neat universally applicable template and the gains to be made from local processes of negotiation and trial and error. The concept of 'building with the materials to hand' is my own offering of a way of conceptualising these processes of adaptation and innovation without falling into the trap of a reified localism or culturalism. Such agendas often claim to revitalise 'traditional' old arrangements to achieve some kind of cultural relevance and legitimacy. However as Manor argues old arrangements cannot be returned to, any attempt at return is in fact a shift to something new (Manor 2008, p.4). Moreover, they are not necessarily viewed as more legitimate, or produce more legitimate outcomes, than what are often perceived in the literature as imported institutions. For example see Crook, Asante and Brobbey's recent work on justice systems in Ghana (2011). In other words this is not to follow the logic of the 'Asian values' interpretation of the rise of developmental states. After all not that long ago Asian cultural values were seen by some as a barrier to economic progress (Kees van Donge, Henley and Lewis 2009, p.13). Rather 'building with the materials to hand' is to follow the arguments made by a number of scholars against the attempt at wholesale importation of structures and institutions (Pritchett, 2010; Evans, 2004; Booth, 2011). The idea of what is 'to hand' is to emphasise that these elements may not be simplistically 'local'. The developmental states of East Asia distinctly did not eschew ideas because they originated externally, however, as this quote from Leftwich indicates they adapted and altered these to their own ends:

"...they were all open to foreign ideas and experience and absorbed, adopted and adapted ideas and advice as appropriate to local circumstances and possibilities. There was no institutional mono-cropping." (Leftwich 2010, p.108)

Essentially building with the materials to hand is an attempt to acknowledge the adaptive and trial and error aspects of building developmental states (White 1998, pp.27-8; Johnson 1982 , p.323). However, whilst these processes are often seen as essential in retrospect, there is very little study of what impact they have on the interactions between states and those wishing to promote development. 
1. If trial and error and adaptation of ideas outside the recommendations of best practice are the most important elements of the way developmental practices come about - what is the role of international development agencies?

2. What were the patterns of external Aid and other forms of external assistance in developmental states?

- What can be learnt from these methods of giving Aid and assistance?

\section{Inclusive development and growth?}

The focus of much of the developmental states literature is on economic development - or growth. The successes of these developmental states are often seen in terms of their increased growth rates. ESID's concerns are focused not only on economic growth but rather on inclusive development and "growth is not automatically or necessarily inclusive". (Leftwich 2008, p.4) Developmental states however base their legitimacy on their developmental results measured by their citizens rising standards of living (Johnson 1987, p.143 and Leftwich 2008, p16). A number of the East Asian developmental states have therefore achieved positive social outcomes in terms of, improved standards of living, health care and education, although, they can also possess problematic levels of accountability and human rights (Leftwich 2008, p.16; 2000, pp.165-166; Pempel 1999). However, Botswana's impressive economic growth has not been matched by decreasing inequality and its economic growth, greatly outstrips its HDI ranking (Meyns 2010, p.45). ${ }^{14}$ This discrepancy and questions more generally about why some developmental states achieve equitable development deserve closer attention.

Redistribution and equity are also key areas that merit further research. Some of the research around land redistribution and agricultural reforms indicate that there needs to be some initial elements which level out the distribution of economic resources (Wade 1990). The emergence of developmental states following on from these agricultural reforms therefore occurs within a context of relative equity. The diminishment of the elite in these scenarios is also significant due to the adverse impact elites can have upon state developmental policies (Evans 1995, p.67-8). The significance of early redistribution for contemporary developmental states thus deserves further research Similarly the role of the developmental state in pursuing redistribution policies deserves further attention.

\section{Possible Research Questions}

1. What explains the discrepancy in wealth sharing between Botswana and the developmental states of East Asia?

- Mineral based development in contrast to industrial based development?

- More homogenous societies in East Asia than Botswana?

- The form of the political settlement in different contexts?

2. Why do elites decide to pursue redistributive policies?

- Discursive understandings of their role and morality?

- To avoid dissent?

- Structural reasons?

3. How significant is the level of economic equity in countries as a precursor to the state pursuing developmental policies?

\footnotetext{
${ }^{14}$ Frustratingly the GINI coefficient data and the Income share held by lowest $10 \%$ statistics data in the statistical review undertaken as part of the preparation of this paper do not show (due to the lack of available data) what levels of improvement or decline there has been in this indicator for Botswana. See Appendix 2.
} 


\section{How does the consensus of conducting developmental roles come about - and how is it sustained?}

Much of the developmental states literature has concentrated on the nature of the developmental structures developmental states require. However, this only looks at part of the story, and Haggard has criticised the literature for its "tendency to address the capacity of the state but not its motivations" (2004, p.70). To be clear the separation out of capacities and motivations is in many respects a heuristic division as it is in part motivations and commitments that produce a professionalised bureaucracy and a professionalised bureaucracy which motivates and induces commitment.

The literature on the developmental state is much hazier about this motivational element than about the institutional structures that worked towards these ends. Haggard observes that when the developmental state literature does deal with the origins of developmental motivations it is looked at as the outcome of one of (or a combination of) four elements: ideology; international constraints on leaders; the material interests of government; and the content of state-society relations. (Haggard 2004, pp.70-71). However all of these need further interrogation as they only provide very shallow answers and generally raise more questions about how these elements work to shift states into taking on developmental roles.

The problem within the developmental states literature is that the decision to pursue these ends via developmental roles is just seen as self-evidently rational as Pempel highlights,

"... developmental state theorists too often treat the national bureaucracy as a

totally depoliticized, socially disembodied, and in rational pursuit of a self evident national interest..." (Pempel, 1999, p.144)

However, national interest is not necessarily self evident, it cannot be assumed to be developmental, it is contested and constructed through many negotiations. Nor can bureaucrats and politicians be assumed to act within the 'national interest' however that is defined. Clearly some states, and some bureaucrats, decide to pursue developmental ends and some do not. There is a process of discursively producing what the goals and incentives are. This occurs not only around the formation of the national interest but also at the more individualised level of bureaucrats. How the national interest is produced as developmental and how bureaucrats and politicians come to view their role in particular ways - for example how norms of professionalism are embedded in the civil service - is often taken for granted. I would suggest however that these processes are perhaps key to understanding how states shift to a developmental focus.

Moreover much of the developmental states literature is thin in its discussion of how a developmental approach is sustained. There has been some discussion of the transition away from developmental states that is seen to be occurring in the case of the East Asian states (Beeson 2004, Chang 2006). With companies which have a significantly altered relationship to the state, that the disciplining role that the developmental state has been seen to play (Wade, 1990; Chang 2006). This is seen to be partly due to their increasingly global nature, in which corporations do not stay rooted to one state. This specific literature is accompanied by an acknowledgement that developmental states come and go, and can be seen to be structures which are in some senses grown out of by design (Fritz and Menocal 2007). However, in contrast to patrimonial developmental states in many cases significant elements of developmental states do not rest on the character of the leader. They are institutionalised or normalised across the bureaucracy and wider sphere of the state and society. What produces this continuity is distinctly underexplored within the literature on developmental states and deserves more attention.

Possible Research Questions 
1. What were the discourses around the emergence of developmental state strategies (i.e. business state co-operation and professionalised civil service) within developmental states?

- What do these tell us about the political environment?

2. What is the role of national sentiment?

- Where does it have the most impact?

- Amongst the elite making decisions about the national interest?

- Amongst those at the bottom who have to 'suffer' to get to greater gains?

3. How do developmental practices gain some continuity?

- How is the bureaucracy professionalised?

- How are developmental practices normalised throughout the state and society?

\section{Patrimonialism, personal rule, development and stability}

Corruption or patrimonialism is one area around which the boundaries of the concept of developmental states blur and fade. There is a slightly schizophrenic element to the arguments in the literature around corruption and its role (or its absence) in the developmental state. There is wide acknowledgement that there were high levels of corruption in many East Asian Developmental States (Hayashi 2010, p. 52; Woo-Cumings 1999, p.16). Yet these practices are often seen to be of a different type to the patrimonialism associated with African states. Patrimonial and clientelism have been seen to be barriers to development in this context (Mkandawire, 2001). APPs recent work on patrimonial developmental states however queries that this is always the case however the types of state capacities which patrimonial developmental leaders build may not have much longevity beyond particular leaders. This could be seen that they are successful in conducting developmental roles for a time but that they do not build the developmental structures or institutions required for these practices to obtain some longevity. This leaves a lot of unanswered questions about the relationship between the developmental state and clientelistic and patrimonial practices.

\section{Possible Research Questions}

1. How different are patrimonial developmental states from developmental states?

- How do they relate to Evans notion of Intermediate States

2. Are patrimonial developmental states a more likely route to developmental outcomes in many states?

3. Can/how can the developmental gains of patrimonial developmental states be prolonged beyond the duration of a particular leader's ability to take charge in a developmental manner?

- In other words how do you institutionalise shift gains made on personal grounds?

\section{Role of education, especially higher/further education}

One area which is frequently mentioned as part of the creation of a effective Weberian civil service is the recruitment of the most capable from the best higher education institutions (Johnson 1982, Evans 1995). The lack of educated personnel in the bureaucracy has also been mentioned as a difficulty elsewhere, for example in implementing economic policies in Indonesia (Hayashi 2010, p.55). However this recruitment pattern can also be found in states which are discussed as 'developmental patrimonial'. (Cammack and Kelsall 2011, p.90; Kelsall and Booth 2010) However, this is not the only role that education performs in developmental states Pempel argues that in the core developmental states, 
"Education...has been heavily geared toward the production of technicians, engineers, and businesspeople, which in turn has also been conducive to economic growth based on manufacturing prowess." (Pempel 1999, p.169)

In addition access to education and continued investment in education has been a key aspect of the egalitarian nature of developmental states (Pempel, 1999, p.169). It was also Evans has argued acted to build capability $(2010 ; 2011)$. Leftwich has highlighted that successful coalition builders often had received high quality education, not only this but they often relied on the networks built through their educational institutions. (Leftwich 2010, p.108) The form of the education system has then been a significant part of the developmental state story. Wade sees investment in education as one of the key factors that have impacted East Asian growth even as its impact is difficult to disentangle from other factors such as industrial policy. (Wade 2010, p.155) Moreover, linking to previous research questions higher education has been seen to play a key role in the development of developmental elites (Brannelly et al. 2011, p. 10). When considering the applicability of the developmental state model elsewhere however the status of the education system seems to somehow be overlooked. This perhaps fits with a wider lack of attention to the role of higher education in development. Williams et al. have recently argued that development agencies need to take the significance of higher education seriously (2011, p.551).

The statistics on this issue are also rather intriguing. Within the top five countries with the highest percentage change in enrolment in tertiary education (amongst the potential developmental states on which we gathered data) are four states which have recently been discussed as potentially emerging developmental states.

Table 2 - Tertiary enrolment, (\% change) over decades - top 5 Developmental States

\begin{tabular}{|c|c|c|}
\hline Country & $\mathbf{1 9 9 0 s}$ & $\mathbf{2 0 0 0 s}$ \\
\hline Ethiopia & $55.39 \%$ & $274.55 \%$ \\
\hline Rwanda & $69.86 \%$ & $246.63 \%$ \\
\hline China & $160.96 \%$ & $214.64 \%$ \\
\hline Tanzania & $90.40 \%$ & $162.62 \%$ \\
\hline Mauritius & $229.33 \%$ & $151.27 \%$ \\
\hline
\end{tabular}

Source of data: WDI Dataset 2011 (World Bank): www.data.worldbank.org [See Appendix 2]

These figures are limited in terms of the number of countries for which they have been calculated. They also give us little insight into the relationship if any between higher education and the emergence of developmental states. But they perhaps do highlight that increased higher education and developmentalism sometimes accompany one another.

\section{Possible Research Questions}

1. What kind of education system produces developmental bureaucrats?

2. What would the nature of education system need to be to produce developmental elites?

3. What developmental or anti-developmental aspects do the education systems of the countries under study have?

- How do these impact the capacity of the bureaucracy?

- How do these alter state-business relations?

\section{The role of resources}

One other area which lacks analysis is how the resource base of the country affects its ability to become a 'developmental state' or produces a different type of developmental state - Botswana is an interesting example here as it has a mainly mineral resources based 
economy in contrast to the economies of many developmental states. The type of development which occurs can be profoundly affected by the type of resources which are being exploited. James Ferguson highlights how the outcomes of foreign direct investment and the social impacts of types of economic activities can greatly vary (2006, pp. 194-210). He contrasts the 'thick' social impact of previous investments in Zambian copper mines, which delivered not only employment but housing, schooling and healthcare for a broad population, with investments in Angolan oil where the social outcomes of these investments are 'thin' sometimes with the oil itself never reaching Angolan soil (Ferguson 2006, pp.197-8). The economic base of the Botswanan developmental state is quite different to that of many other developmental states being based on diamond mining. Botswana has also been noted for having less equitable development than many developmental states (Meyns 2010). The majority of developmental sates have upgraded to a more industrial based economy which has often been socially thick in its impacts with company towns being a feature in Korea perhaps even more so than in the Zambian copper belt (REF). The correlation of divergent income distribution in Botswana raises interesting questions for the emergence of new developmental states and what impact the economic base of their developmental may have. It perhaps also raises the question - first broached in the introduction - of whether 'truly developmental' states need to undergo a process of upgrading their economy. However, Botswana is a single case and perhaps speedy conclusions cannot be, or should not be drawn without further investigation.

\section{Possible Research Questions}

1. How does a country's resource base impact on its ability to become a developmental state?

- Is a lack of resources in some senses helpful? (cf. (Doner, Ritchie and Slater 2005)

2. Given the example of Botswana are the political elements of how resources and the revenue from them managed more salient than just the resource base?

\section{Importance of rural/agriculture policies}

It is often suggested in the literature that the removal of powerful landed elites paved the way for the emergence of developmental states (Evans 1995; 2011). Kees van Donge, Henley, and Lewis in particular argue that the mergence of developmental states rests on the adoption of particular agricultural policies which benefit the income of peasant farmers (2009). However, whilst this is fairly widely contended as a precondition of the emergence of developmental states much less attention has been paid to this area of research to for example industrial policy. Although there is however a current research project Tracking Development which is pursuing some of these themes and is the project that the Kees van Donge, Henley, and Lewis paper comes out of. ${ }^{15}$ This area of research is perhaps particularly important when considering how other states could move towards undertaking developmental policies as they may not be able to emulate East Asian industrial growth without first addressing agricultural policy. Some attempts to copy western economies have been seen to fail as they were overly ambitious and did not spend the time building steady foundations. It is therefore important to know what elements are foundational for pursuing a developmental state strategy.

Possible Research Questions

- Are these agricultural policies are the building blocks for future developmental state policies?

\footnotetext{
${ }^{15}$ More information about this project can be found at http://www.trackingdevelopment.net/
} 
- If so how can consideration of pro-poor rural policies play a part in improving developmental outcomes elsewhere?

- Does it depend upon the makeup of a state's economy and resources how important these agricultural policies are?

\section{Possible methods and case studies}

There are a large diversity of areas for future research and a plethora of research questions which arise out of this literature review. This section tentatively suggests some innovative ways of approaching these issues methodologically and some key countries that could serve as interesting case studies or comparative cases.

\section{Cross country quantitative comparisons}

A number of the questions raised above could benefit from approaches examining a cross section of countries - perhaps in line with the preliminary statistics on 25 countries examined in Appendix 2. These explorations may not provide fully satisfactory findings in themselves however they may offer to highlight interesting cases for further exploration by qualitative means. These could examine issues such as:

- Comparative statistics on the relationship between the equity of growth within a country and a) the economic base of a country's development and b) the homogeneity of the county.

- Examination of the numbers in higher education and the numbers of those entering the civil service in relation to the emergence of the developmental state.

- An examination of the growth patterns of states following significant pro-poor rural policies being taken up and/or significant land redistribution being undertaken.

\section{Historical analysis}

One issue which is touched upon but not laid out clearly in the developmental states literature is the detailed story of how aid was given and managed. This would perhaps make a useful study to utilise to consider further the role of aid in the advent of developmental states.

\section{'Ethnographic' research on the bureaucracy}

Recently there has been more ethnographic work conducted on the public's interactions with bureaucracy especially around corruption in Africa. This move has been led by Olivier de Sardan and Giorgio Blundo (Blundo and Olivier de Sardan, 2006; Blundo and Le Meur, 2009b). However, Akhil Gupta has also conducted similar work in India (Gupta, 1995). There is an acknowledgement in this literature however that more work is needed in the 'back room' to understand not only the interactions of bureaucrats with the public, but to understand the practices and motivations of bureaucrats more generally in their social embeddedness (Blundo and Le Meur 2009, pp. 21-22).

This approach focussing on bureaucrats within their social environment could provide many interesting insights for the literature on developmental states which has seen bureaucrats as key, but has not explored the complexities of the social worlds in which they operate. It may in particular allow access to the complexities of decisions to undertake developmental roles. This would also compliment and build on literature which has examined patrimonial systems using these more ethnographic approaches and would allow for key differences to be drawn out. This work may be particularly interesting in emerging developmental states in order to observe changing bureaucratic and political imperatives and how these perhaps produce bureaucrats whose practices are possibly more Weberian? and/or possibly more 
developmental? It would allow for the interrogation of the impact of elements such as higher education and social networks on the functioning of the state. Participant observation can be complimented by semi-structured interviews with bureaucrats as well as perhaps with other key constituents, students attempting to enter the civil service for example.

This work would build on research undertaken by the Thomas Bierschenk and others on the interface bureaucrats in Ghana, Mali, Benin and Niger (Biershenk 2010). It would however offer to explore further the ways in which the national project expounded and devotedly advanced by developmental states alters not only policies but also the bureaucratic subjectivities and professionalism of the bureaucrats which make up the state and are the medium through which the state is experienced by society. This professional demeanour is often seen as lacking in bureaucrats in the literature on West Africa (Biershenk 2010; Blundo and Olivier de Sardan 2006). This stands in stark contrast to the professional bureaucracy highlighted in early developmental states (Evans 1995, Johnson 1982).

\section{Possible case studies}

Botswana and Mauritius being outside the main East Asian success story but still being widely considered developmental states make key case studies to be considered. Mauritius is perhaps particularly interesting as it has achieved industrialisation and has negotiated its access to markets outside of the geo-political specificities of the North East Asian situation (Meisenhelder, 1997). Botswana however represents a peculiar case of natural resource based developmentalism - for which I can not think of another parallel. Its unusalness therefore automatically makes it a case ripe for study.

'Promising' or aspirational developmental regimes South Africa Ethiopia and Rwanda are also perhaps important countries to be studied as they have been discussed as states in which developmental tendencies are newly emerging. Studying these states would perhaps give insight into newly emerging trends, policies and problems.

These aspirational states could perhaps be usefully compared with a state such as Ghana which is not usually considered to be a developmental state, yet has achieved good progress against some development indicators, notably some of the MDGs. This comparison may help to illuminate specifics about the role of the state in development more broadly, outside of a very particular set of state-society relations that the developmental state model implies. It would also offer a interesting reference point for states which are utilising developmental state rhetoric such as Ethiopia.

Again China perhaps also offers a key case study given its recent meteoric economic growth and its particular set of relationships between the Chinese state and Chinese business. The BRIC countries in general would make interesting case studies of the state's role in development Brazil in particular having had a very different state-society engagement than the East Asian states. Also there has been a recent interest in sub-state level instances of developmental governance and India provides a good location to study this phenomena. It also allows perhaps a good comparative location. The comparison of two Indian states may allow for the most influential factors on developmentalism to be isolated and for the relationship between regional developmental entities and the federal level to be explored. 


\section{References}

Abrahamsen, R. (2000). Disciplining Democracy: Development Discourse and Good Governance in Africa. London: Zed Books.

Abrams, P. (1988). Notes on the Difficulty of Studying the State (1977). Journal of Historical Sociology, 1(1), 58-98.

Acemoglu, D., Johnson, S. \& Robinson, J. A. (2000). The Colonial Origins of Comparative Development. Cambridge, MA: National Nureau of Economic Research.

Acemoglu, d., Johnson, S. \& Robinson, J. A. (2002). An African Success Story: Botswana. London: Centre for Economic Policy Research.

Africa Focus. (2011). Africa: ECA Calls for Developmental States [Online]. Available: http://www.africafocus.org/docs11/eca1103.php [Accessed 1 Sept 2011].

Amsden, A. (1989). Asia's Next Giant: South Korea and Late Industrialisation. Oxford Oxford University Press.

Amsden, A. (2011). Comments - Growth Identification and Facilitation: The Role of the State in the Dynamics of Structural Change. Development Policy Review 29(3), 292-94.

Anderson, B. (2006). Imagined Communities: Reflections on the Origin and Spread of Nationalism. London: Verso.

Andreosso-O'Callaghan, B. (2004). The Role of the Irish State in the Catching-Up Process: Developmental or Growth-Promoter? In: Low, L. (ed.) Developmental States: Relevancy, Redundancy or Reconfiguration? New York: Nova Science Publishers.

Bateman, M., Pablo, J., Ortíz, D. \& Maclean, K. (2011). A post-Washington consensus approach to local economic development in Latin America? An example from Medellín, Colombia. London: Overseas Development Institute.

Bayart, J.-F., Ellis, S. \& Hibou, B. (1999). The Criminalisation of the State in Africa. Oxford: James Currey.

Beeson, M. (2004). The Rise and Fall (?) of the Developmental State: The Vicissitudes and Implications of East Asian Interventionism. In: Low, L. (ed.) Developmental States Relevancy, Redundancy and Reconfiguration. New York: Nova Science Publishers.

Bierschenk, T. (2010). States at Work in West Africa: Sedimentation, Fragmentation and Normative Double-Binds. Mainz: Department of Anthropology and African Studies, Johannes Gutenberg-Universität.

Blundo, G. \& Meur, P.-Y. L. (2009a). An Anthropology of Everyday Governance: Collective Service Delivery and Subject Making. In: Blundo, G. \& Meur, P.-Y. L. (eds.) Governance of Daily Life in Africa: Ethnographic Explorations of Public and Collective Services. Leiden: Brill.

Blundo, G. \& Meur, P.-Y. L. (eds.) (2009b). The Governance of Daily Life in Africa: Ethnographic Explorations of Public and Collective Services, Leiden: Brill.

Blundo, G. \& Olivier de Sardan, J.-P. (2006). Everyday Corruption and the State: Citizens and Public Officials in Africa. London: Zed Books.

Booth, A. (2005). Did it Really Help to be a Japanese Colony?: East Asian Economic Performance in Historical Perspective. Singapore: Asia Research Institute.

Booth, A. (2007). Night watchmen, Exstractive or Developmental States? Some evidence from late colonial South-east Asia. Economic History Review, 60(2), 241-266. 
Booth, D. (2010). Towards a Theory of Local Governance and Public Goods in sub-Saharan Africa. London: Africa Power and Politics Programme.

Booth, D. (2011). Governance for development in Africa: building on what works. London: Africa Power and Politics Programme.

Booth, D. \& Golooba-Mutebi, F. (2011). Developmental patrimonialism? The case of Rwanda. London: Africa Power and Politics Programme.

Brannelly, L., Lewis, L. \& Ndaruhutse, S. (2011). Higher Education and the Formation of Developmental Elites Developmental Leadership Programme.

Bräutigam, D., Rakner, L. \& Taylor, S. (2002). Business associations and growth coalitions in Sub-Saharan Africa. Journal of Modern African Studies, 40(4), 519-547.

Cammack, D. \& Kelsall, T. (2010). Developmental patrimonialism? The case of Malawi. London: Africa Power and Politics Programme.

Cammack, D. \& Kelsall, T. (2011). Neo-patrimonialism, Institutions and Economic Growth: The Case of Malawi, 1964-2009. IDS Bulletin, 42(2), 88-96.

Chang, H.-J. (2006). The East Asian development experience: the miracle, the crisis and the future. London: Zed Books.

Chu, Y.-w. (2004). Hong Kong: from Laissez Faire to Experments in Developmental Support. In: Low, L. (ed.) Developmental States: Relevancy, Redundancy or Reconfiguration? New York: Nova Science Publishers

Cohen, J. L. \& Arato, A. (1994). Civil society and Political Theory. Cambridge, Mass: MIT Press.

Crook, R. C., Asante, K. P. \& Brobbey, V. K. (2011). Popular Concepts of Justice and Hybrid Judical Institutions in Ghana. IDS Bulletin, 42(2), 64-75.

Di John, J. \& Putzel, J. (2009). Political Settlements: Issues Paper. Government and Social Development Resource Centre.

Diamond, L. (2008). The Democratic Rollback: The Resurgence of the Predatory State. Foreign Affairs, 87(2), 36-48.

Doner, R. F., Ritchie, B. K. \& Slater, D. (2005). Systematic Vulnerability and the Origins of Developmental States: Northeast and Southeast Asia in Comparative Perspective. International Organisation, 59, 327-361.

Edigheji, O. (2005). A Democratic Developmental State in Africa?: A concept paper. Johannesburg: Centre for Policy Studies.

Edigheji, O. (ed.) (2011). Constructing a democratic developmental state in South Africa: Potentials and challenges, Cape Town: Human Sciences Research Council.

Englund, H. (2006). Prisoners of Freedom: Human Rights and the African Poor. Berkely: University of California Press.

Evans, P. (1995). Embedded Autonomy: States and Industrial Transformation. Princeton, NJ: Princeton University Press.

Evans, P. (1998). Transferable lessons? Re-examining the institutional prerequisites of East Asian economic policies. Journal of Development Studies, 34(6), 66-86.

Evans, P. (2004). Development as Institutional Change: The Pitfalls of Monocropping and Potentials of Deliberation. Studies in Comparative International Development, 38(4), 3052. 
Evans, P. (2010). The Challenge of 21st Century Development: Building Capability Enhancing States. New York: United Nations Development Programme.

Evans, P. (2011). Constructing the 21st Century Developmental State. In: Edigheji, O. (ed.) Constructing a democratic developmental state in South Africa: Potentials and challenges. Cape Town: Human Sciences Research Council.

Fakir, E. (2007). Public Service Delivery in a Democratic, Developmental State. Johannesburg: Centre for Policy Studies.

Ferguson, J. (2006). Global Shadows: Africa in the Neo-liberal World Order. Durham, NC: Duke University Press.

Foucault, M. (1995). Discipline and Punish: The Birth of the Prison. New York: Random House.

Fritz, V. \& Menocal, A. R. (2007). Developmental States in the New Millennium: Concepts and Challenges for a New Aid Agenda. Development Policy Review, 25(5), 531-552.

Gregor, A. J. (1979). Italian fascism and developmental dictatorship. Princeton: Princeton University Press.

Gupta, A. (1995). Blurred Boundaries: the discourse of corruption, the culture of politics, and the imagined state. American Ethnologist, 22(2), 375-402.

Gupta, A. \& Sharma, A. (2006). Rethinking Theories of the State in an Age of Globalisation. The Anthropology of the State: A Reader. Oxford: Blackwell.

Gyimah-Boadi, E. (2009). A "liberal" developmental state in Ghana: an emerging paradigm for democracy and economic growth? Accra: Centre for Democracy and Development.

Haggard, S. (2004). Institutions and Growth in East Asia. Studies in Comparative International Development, 138(4), 53-81.

Haggard, S., Kang, D. \& Moon, C.-I. (1997). Japanese Colonialism and Korean Development: A Critique. World Development, 25(6), 867-881.

Hall- Mathews, D. (2007). Tickling Donors and Tackling Opponents: The Anti-Corruption Campaign in Malawi. In: Bracking, S. (ed.) Corruption and Development: The AntiCorruption Campaigns. Basingstoke: Macmillian.

Hayashi, S. (2010). The developmental state in the era of globalization: beyond the Northeast Asian model of political economy. The Pacific Review, 23(1), 45-69.

Henley, D. (undated). Three Principles of Successful Development Strategy: Outreach, Urgency, Expediency. Leiden: Tracking Devlopment.

Herring, R. J. (1999). Embedded Particularism: India's Failed Developmental State. In: WooCumings (ed.) The Developmental State. Ithaca, NY: Cornell University Press.

Hjort, J. (2010). Pre-colonial culture, post-colonial economic success? The Tswana and the African economic miracle. Economic History Review, 63(3), 688-709.

Hobson, J. M. (2001). The 'second state debate' in International Relations: theory turned upside-down. Review of International Studies, 27(3), 395-414.

Howell, J. (2006). Reflections on the Chinese State. Development and Change, 37(2), 273297.

Hutchinson, F. E. (2008). "Developmental" States and Economic Growth at the Sub-National Level: The Case of Penang. Southeast Asian Affairs.

Jackson, R. H. \& Rosberg, C. G. (1982). Why Africa's Weak States Persist: The Empirical and the Juridical in Statehood. World Politics, 35(1), 1-24. 
Jenkins, R. (1991). The Political Economy of Industrialization: A Comparision of Latin American and East Asian Newly Industrialising Countries. Development and Change, 22, 197-231.

Jian-xing, Y. \& De-jin, S. (2010). The Developmental State and Beyond: The Case of China. Fudan Journal of the Humanities and Social Sciences, 3(4), 42-66.

Johnson, C. (1982). MITI and the Japanese Miracle. Stanford: Stanford University Press.

Johnson, C. (1987). Political Institutions and Economic Performance: the GovernmentBusiness Relationship in Japan, South Korea, and Taiwan. In: Deyo, F. C. (ed.) The Political Economy of the New Asian Industrialisation. Ithaca, NY: Cornell University Press.

Johnson, C. (1999). The Developmental State: Odyssey of a Concept. In: Woo-Cumings, M. (ed.) The Developmental State. Ithaca, NY

Jomo, K. S. (2004). Southeast Asian Developmental States in Comparative Eastasian Perspective. In: Low, L. (ed.) Developmental States: Relevancy Redundancy or Reconfiguration. New York: Nova Science.

Kees van Donge, J., Henly, D. \& Lewis, P. (2009). Tracking Development in South East Asia and Sub-Saharan Africa: The Primacy of Policy. Available: http://www.trackingdevelopment.net/resources/docs/TD\%20in\%20SA\%20and\%20SSA T he\%20primacy\%20of\%20policy.pdf.

Kellsal, T. \& Booth, D. (2010). Developmental Patrimonialism? Questioning the orthodoxy on political governance and economic progress in Africa. London: Africa Power and Politics Programme.

Kohli, A. (1994). Where do high growth political economies come from? The Japanese linage of Korea's "Developmental State". World Development, 22(9), 1269-1293.

Kohli, A. (2004). State-Directed Development: Political Power and Industrialization in the Global Periphery. Cambridge: Cambridge University Press.

Kuznets, P. W. (1988). An East Asian Model of Economic Development: Japan, Taiwan, and South Korea. Economic Development and Cultural Change, 36(3), S11-S43.

Leftwich, A. (1995). Bringing politics back in: Towards a model of the developmental state. Journal of Development Studies, 31(3), 400-427.

Leftwich, A. (2000). States of Development: On the Primacy of Politics in Development. Cambridge: Polity Press.

Leftwich, A. (2008). Developmental states, effective states and poverty reduction: The primacy of politics. Geneva: UNRISD Project on Poverty Reduction and Policy Regimes.

Leftwich, A. (2010). Beyond Institutions: Rethinking the Role of Leaders, Elites andf Coalitions in the Industrial Formation of Developmental States and Strategies. Forum for Development Studies, 37(1), 93-111.

Lin, J. \& Monga, C. (2011). Growth Identification and Facilitation: The Role of State in Dynamics of Structural Change. Development Policy Review, 29(3), 264-290.

List, F. (1904). The national system of political economy. London: Longmans, Green and Co.

Livingston, D. (1992). The Geographical Tradition. Oxford: Blackwell.

Lockwood, M. (2005). The State They're In: An Agenda for International Action on Poverty in Africa. Burton-on-Dunsmore: ITDG Publishing.

Low, L. (2004a). Developmental States: Relevancy, Redundancy or Reconfiguration. New York Nova Science Publishers. 
Low, L. (2004b). Singapore's Developmental State between a Rock and a Hard Place. In: Low, L. (ed.) Developmental States: Relevancy, Redundancy or Reconfiguration? New York: Nova Science Publishers.

Manor, J. (2008). An Asianist's perspecitive on the Africa Power and Politics Programme. London: Africa Power and Politics Programme.

Mbabazi, P. \& Taylor, I. (2005). Botswana and Uganda as Developmental States (?). In: Mbabazi, P. \& Taylor, I. (eds.) The Potentiality of 'Developmental States' in Africa: Botswana and Uganda compared Dakar: CODESRIA.

Meisenhelder, T. (1997). The Developmental State in Mauritus. Journal of Modern African Studies, 35(2), 279-297.

Meyns, P. (2010). Botswana - A Developmental State in Africa. In: Meyns, P. \& Musamba, C. (eds.) The Developmental State in Africa: Problems and Prospects. Institute for Development and Peace (INEF), University of Duisburg-Essen.

Meyns, P. \& Musamba, C. (2010). The Developmental State in Africa: Problems and Prospects. Institue for Development and Peace, University of Duisburg-Essen

Mitchell, T. (2006). Society, Economy and the State Effect. In: Sharma, A. \& Gupta, A. (eds.) The Anthropology of the State: A Reader. Oxford: Blackwell.

Mkandawire, T. (2001). Thinking about Developmental States in Africa. Cambridge Journal of Economics, 25, 289-313.

Moon, C.-I. \& Prasad, R. (1994). Beyond the Developmental State: Networks, Politics and Institutions. Governance: An International Journal of Policy and Administration, 7(4), 360386.

Musamba, C. (2010). The Developmental State Concept and its Relevance for Africa. In: Meyns, P. \& Musamba, C. (eds.) The Developmental State in Africa: Problems and Prospects. Institute for Development and Peace (INEF), University of Duisburg-Essen.

$\mathrm{Neo}, \mathrm{H}$. (2007). Challenging the developmental state: Nature conservation in Singapore. Asia Pacific Viewpoint, 48(2), 186-199.

New Business Ethiopia. (2011). Meles Prescribes Developmental State Paradigm for African States [Online]. Available: http://newbusinessethiopia.com/index.php?option=com content\&view=article\&id=462:mel es-prescribes-developmental-state-development-paradigm-for-africa-\&catid=13:regionalpolitics\&ltemid=6 [Accessed 1 Sept 2011].

North, D. C., Wallis, J. J., Webb, S. B. \& Weingast, B. R. (2007). Limited Access Orders in the Developing World: A New Approach to the Problems of Development. The World Bank, Independent Evaluation Group, Country Relations Division.

Parks, T. \& Cole, W. (2010). Political Settlements: Implications for International Development Politcy and Practice. The Asia Foundation.

Pempel, T. J. (1999). The Developmental Regime in a Changing World Economy. In: WooCumings, M. (ed.) The Developmental State. Ithaca, NY: Cornell University Press.

Petiteville, F. (1998). Three mythical representations of the state in development theory. International Social Science Journal, 50(155), 115-124.

Poteete, A. R. (2009). Is Development Path Dependent or Political? A Reinterpretation of Mineral-Dependent Development in Botswana. Journal of Development Studies, 45(4), 544-571.

Pritchett, L. (2010). Fragile States: Stuck in a Capability Trap? . World Development Report Background Paper 
Putzel, J. (2002). Developmental States and Crony Capitalists In: Masina, P. P. (ed.) Rethinking Development in East Asia. Richmond, Surrey: Curzon Press.

Rains, G. \& Orrock, L. (1985). Latin American and East Asian NICs: Development Stategies Compared. In: Duran, E. (ed.) Latin America and the World Recession. Cambridge: Cambridge University Press.

Ramseyer, J. M. \& Rosenbluth, F. M. (1993). Japan's Political Market Place. Cambridge, MA: Harvard University Press.

Randall, V. (2007). Political Parties and Democratic Developmental States. Development Policy Review, 25(5), 633-652.

Roth, G. (1968). Personal Rulership, Patrimonialism and Empire-building in the New States. World Politics, 20, 194-206.

Sandbrook, R. (2005). Origins of the Democratic Developmental State: Interogating Mauritius. Canadian Journal of African Studies, 39(3), 549-581.

Sandbrook, R., Edelman, M., Heller, P. \& Teichman, J. (2007). Social Democracy in the Global Periphery. Cambridge: Cambridge University Press.

Taylor, I. (2005). The Developmental State in Africa: The Case of Botswana. In: Mbabazi, P. \& Taylore, I. (eds.) The Potentiality of 'Developmental States' in Africa. Dakar: CODESRIA.

Trouillot, M.-R. (2001). The Anthropology of the State in the Age of Globalization: Close Encounters of the Deceptive Kind. Current Anthropology, 42(1), 125-138.

Unsworth, S. (2009). What's politics got to do with it?: Why donors find it so hard to come to terms with politics, and why this matters. Journal of International Development, 21(6), 883-894.

$\mathrm{Vu}, \mathrm{T}$. (2007). State Formation and the Origins of Developmental States in South Korea and Indonesia. Studies in Comparative International Development, 41(4), 27-56.

Wade, R. (1990). Governing the Market: Economic Theory and the Role of Government in East Asian Industrialisation. Princeton, NJ Princeton University Press.

Wade, R. (2003). What strategies are viable fo developing countries today? The World Trade Organization and the shreinking of 'development space'. Review of International Political Economy, 10(4), 621-644.

Wade, R. (2010). After the Crisis: Industrial Policy and the Developmental State in LowIncome Countries. Global Policy, 1(2), 150-161.

Weber, M. (1978). Economy and Society Vol. 2. Berkeley: University of California Press.

Weber, M. (1991). Politics as Vocation. In: Gerth, H. H. \& Turner, B. S. (eds.) From Max Weber: essays in sociology. Abingdon: Routledge.

White, G. (1988a). State and Market in China's Socialist Industrialisation. In: White, G. (ed.) Developmental States in East Asia. Basingstoke: The Macmillan Press.

White, G. (1988b). State and Market in China's Socialist Industrialisation. In: White, G. (ed.) Developmental States in East Asia. Basingstoke: The Macmillan Press.

White, G. (1998). Building a Democratic Developmental State: Social Democracy in the Developing World. Democratization, 5(3), 1-32.

White, G. \& Wade, R. (1988). Developmental States and Markets in East Asia: An Introduction. In: White, G. (ed.) Developmental States in East Asia. Basingstoke: The Macmillan Press. 
Williams, G., Duncan, A., Landell-Mills, P. \& Unsworth, S. (2011). Politics and Growth. Development Policy Review, 29(s1), s29-s55.

Woo-Cumings, M. (1999). Introduction: Chalmers Johnson and the Politics of Nationalism and Development. In: Woo-Cumings, M. (ed.) The Developmental State. Ithaca, NY: Cornell University.

Young, C. (1988). The African Colonial State and its Political Legacy. In: Rothchild, D. \& Chazan, N. (eds.) The Precarious Balance: State and Society in Africa. Boulder: Westview.

Young, C. (1995). The Heritage of Colonialism. In: Harbeson, J. W. \& Rothchild, D. (eds.) Africa in World Politics. Boulder: Westview. 


\section{Appendix 1 - Previous research on Developmental States: summary of key empirical studies}

\begin{tabular}{|c|c|c|}
\hline Study & Sample, description, study period and methodology & Summary of findings and conclusions \\
\hline $\begin{array}{l}\text { Johnson, } \\
1982\end{array}$ & $\begin{array}{l}\text { Institutional history of Japanese Ministry of International } \\
\text { Trade and Industry } 1925-1975 \text {. }\end{array}$ & $\begin{array}{l}\text { The book is one of the first works to utilise the term developmental state. } \\
\text { Japan is seen to be a developmental state, employing a particular set of state - } \\
\text { business relations often through the MITI and particular industrial policy. A } \\
\text { model of the Japanese developmental state is given in the final chapter. }\end{array}$ \\
\hline Amsden, 1989 & Case Study of Korea's industrialisation process. & $\begin{array}{l}\text { The book concludes that Korea and other late industrialisers (in this group she } \\
\text { includes India, Brazil and Japan) are following a similar patter than involves the } \\
\text { state intervening in the market to assist business. This she argues benefits } \\
\text { rather than harms the broader national interest. Her conclusions also } \\
\text { challenge assumptions about competitive advantage, as late industrialisers can } \\
\text { change their competitive advantage through their investment in Research and } \\
\text { Design ( } R \text { and } D) \text {. }\end{array}$ \\
\hline Wade, 1990 & $\begin{array}{l}\text { Examines empirically theoretical explanations for the } \\
\text { growth of East Asian states. Focuses on the industrial } \\
\text { and economic policy of Taiwan. Conclusions are drawn } \\
\text { from an analysis of economic conditions, sectoral histories } \\
\text { and policy analysis }\end{array}$ & $\begin{array}{l}\text { The book concludes that what he coins the governed market (GM) gives the } \\
\text { most convincing explanation of the drivers behind the rapid growth of East } \\
\text { Asian states. The GM involves the implementation of particular industrial and } \\
\text { economic policies by the state which steer industry in to higher wage more } \\
\text { profitable sectors. }\end{array}$ \\
\hline $\begin{array}{l}\text { Ramseyer and } \\
\text { Rosenbluth, } \\
1993\end{array}$ & $\begin{array}{l}\text { Japanese Political System, approx. 1950s - 1990s. } \\
\text { Choice theoretic analysis. }\end{array}$ & $\begin{array}{l}\text { The book conducts an assessment of the Japanese political system arguing } \\
\text { that it is in line with the choice theoretic method of understanding politics as the } \\
\text { principle agents operate within the institutional rules of the game. }\end{array}$ \\
\hline Evans, 1995 & $\begin{array}{l}\text { Examination of role of the state in industrial growth } \\
\text { especially through an examination of the Information } \\
\text { Technology (IT) Industry. The case studies are drawn } \\
\text { from New Industrialising Countries and comprise Brazil, } \\
\text { India and Korea during the 1970s and 1980s. }\end{array}$ & $\begin{array}{l}\text { The book argues that successful industrial transformation requires that the } \\
\text { state's bureaucracy is both autonomous from business interests in terms of } \\
\text { making decisions which focus on a broader national interest but that it is also } \\
\text { embedded within in them in order to have the understanding it requires to } \\
\text { manage the industrialisation process. }\end{array}$ \\
\hline
\end{tabular}




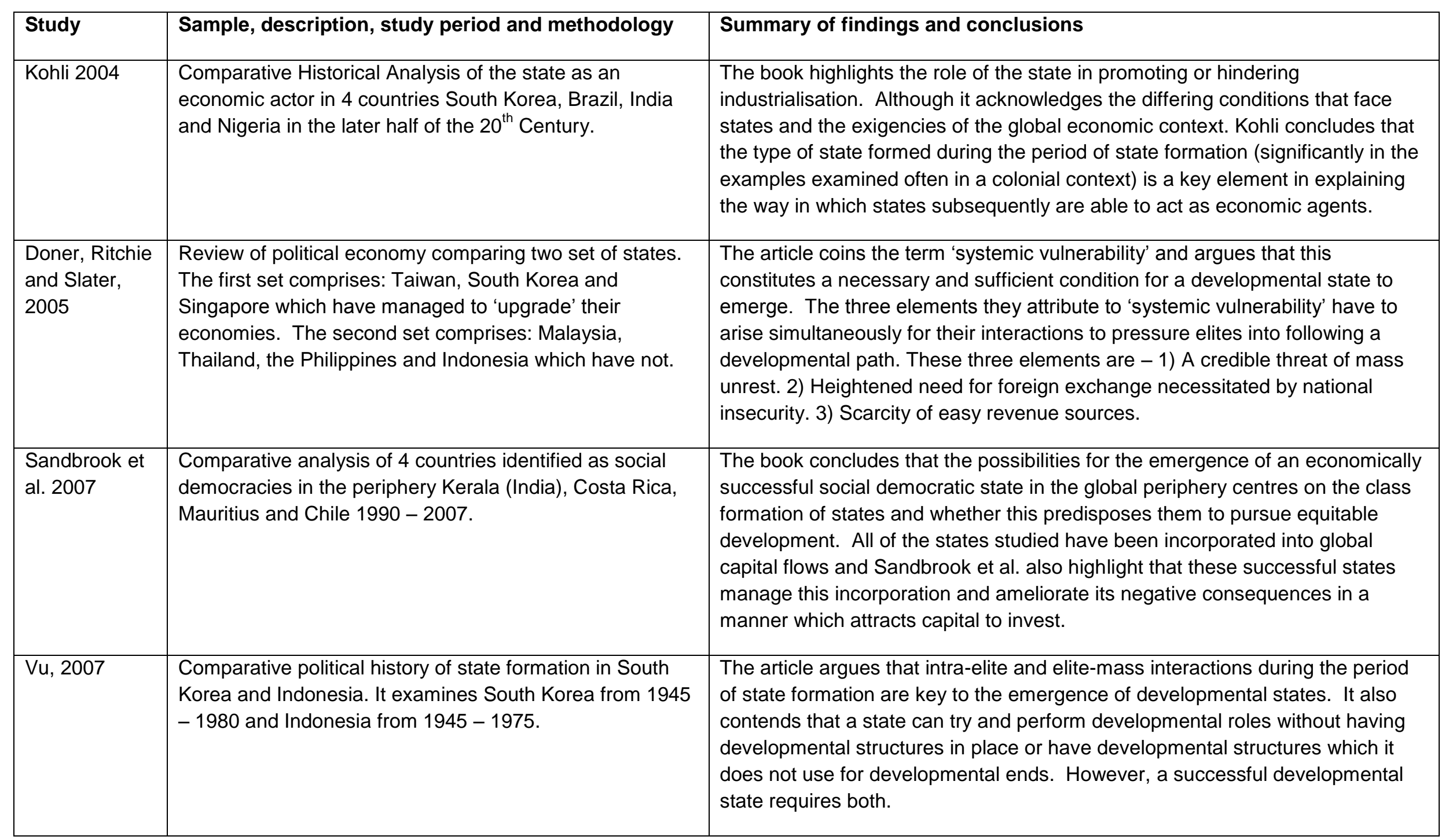




\begin{tabular}{|l|l|l|}
\hline Study & Sample, description, study period and methodology & Summary of findings and conclusions \\
\hline $\begin{array}{l}\text { Kees van } \\
\text { Donge, } \\
\text { Henley and } \\
\text { Lewis, 2009 }\end{array}$ & $\begin{array}{l}\text { Comparison of development trends and policies } \\
\text { undertaken in countries form South East Asia and Sub- } \\
\text { Saharan Africa. Approx 1960s to 2000s. }\end{array}$ & $\begin{array}{l}\text { The paper argues that South East Asia's development successes were built } \\
\text { upon pro-poor rural/agricultural policies. The absence of these in case of Sub- } \\
\text { Saharan Africa is seen to account for its low levels of development and } \\
\text { unsuccessful industrialisation. }\end{array}$ \\
\hline $\begin{array}{l}\text { Kelsall and } \\
\text { Booth, 2010 }\end{array}$ & $\begin{array}{l}\text { Examines the hypothesis of a link between long-horizon } \\
\text { centralised rent processes and economic growth. It } \\
\text { examines 5 African countries Côte d'Ivoire, Malawi, } \\
\text { Kenya, Rwanda and Tanzania during periods identified as } \\
\text { characterised by long-horizon centralised rent processes. } \\
\text { It then analyses the economic and political landscape of } \\
\text { these periods to examine whether there is a connection } \\
\text { between long-horizon centralised rent processes and } \\
\text { economic growth. }\end{array}$ & $\begin{array}{l}\text { The paper concludes that there is a connection between long-horizon } \\
\text { centralised rent processes and economic growth. But that on its own these } \\
\text { processes are not sufficient. The the role a skilled leader assisted by a } \\
\text { competent bureaucracy is seen to be probably another key element which } \\
\text { works with the long-horizon centralised rent processes to achieve economic } \\
\text { growth. }\end{array}$ \\
\hline $\begin{array}{l}\text { Henley } \\
\text { undated (circa } \\
\text { 2010-2011). }\end{array}$ & $\begin{array}{l}\text { Comparison of development strategies undertaken in } \\
\text { Malaysia and Indonesia with development strategies } \\
\text { undertaken in Nigeria and Kenya in the post-war period. }\end{array}$ & $\begin{array}{l}\text { The paper concludes that development strategies in Malaysia and Indonesia } \\
\text { have been more successful than those within Nigeria and Kenya because they } \\
\text { have focused on reaching the largest number of people in contrast to Kenya } \\
\text { and Nigeria whose approach has often been on more narrow but perhaps more } \\
\text { ambitious projects. }\end{array}$ \\
\hline
\end{tabular}




\section{Appendix 2 - Statistics on developmental and potential developmental states}

This appendix presents some preliminary statistics on the progress of states considered to be developmental or potentially developmental. The selection of countries as potentially developmental is based on the review of the literature and consultation with ESID colleagues. The statistics were compiled by University of Manchester MA student Mauricio Moscoso; the source of the data is indicated at the bottom of each table.

\begin{tabular}{|c|c|c|c|}
\hline & \multicolumn{3}{|c|}{ HDI Value (\% change) } \\
\hline COUNTRY & $1980-1990$ & $1990-2000$ & $2000-2010$ \\
\hline Bangladesh & $20.85 \%$ & $24.60 \%$ & $20.26 \%$ \\
\hline Botswana & $33.64 \%$ & $-0.69 \%$ & $10.66 \%$ \\
\hline Brazil & $0.00 \%$ & $8.17 \%$ & $7.70 \%$ \\
\hline Chile & $11.20 \%$ & $8.74 \%$ & $6.68 \%$ \\
\hline China & $25.00 \%$ & $23.26 \%$ & $16.93 \%$ \\
\hline Costa Rica & $6.68 \%$ & $7.04 \%$ & $5.99 \%$ \\
\hline Ethiopia & $0.00 \%$ & $25.00 \%$ & $31.20 \%$ \\
\hline Ghana & $9.92 \%$ & $8.02 \%$ & $8.35 \%$ \\
\hline Hong Kong & $11.69 \%$ & $3.36 \%$ & $7.75 \%$ \\
\hline India & $21.56 \%$ & $13.11 \%$ & $17.95 \%$ \\
\hline Indonesia & $17.44 \%$ & $9.17 \%$ & $20.00 \%$ \\
\hline Israel & $5.35 \%$ & $6.85 \%$ & $3.56 \%$ \\
\hline Japan & $5.99 \%$ & $5.04 \%$ & $3.39 \%$ \\
\hline $\begin{array}{l}\text { Korea } \\
\text { (Rep.) }\end{array}$ & $17.69 \%$ & $12.41 \%$ & $7.61 \%$ \\
\hline Malawi & $12.02 \%$ & $19.03 \%$ & $11.92 \%$ \\
\hline Malaysia & $13.86 \%$ & $12.18 \%$ & $7.67 \%$ \\
\hline Mauritius & $14.67 \%$ & $9.14 \%$ & $6.70 \%$ \\
\hline Rwanda & $-13.65 \%$ & $28.84 \%$ & $38.99 \%$ \\
\hline Singapore & $0.00 \%$ & $14.29 \%$ & $5.75 \%$ \\
\hline $\begin{array}{l}\text { South } \\
\text { Africa }\end{array}$ & $0.17 \%$ & $-0.17 \%$ & $-0.50 \%$ \\
\hline Sri Lanka & $8.77 \%$ & $7.53 \%$ & $9.67 \%$ \\
\hline Tanzania & - & $0.91 \%$ & $19.88 \%$ \\
\hline Thailand & $13.04 \%$ & $9.89 \%$ & $9.00 \%$ \\
\hline Turkey & $18.20 \%$ & $13.95 \%$ & $7.95 \%$ \\
\hline Uganda & $-6.33 \%$ & $24.56 \%$ & $20.57 \%$ \\
\hline Vietnam & $1.75 \%$ & $24.08 \%$ & $13.27 \%$ \\
\hline Taiwan & - & - & - \\
\hline
\end{tabular}

Source of data : UNDP Stats, website: http://hdrstats.undp.org/en/tables/default.html; Global Market Information Database [Accessed through ESDS UK] 


\begin{tabular}{|c|c|c|}
\hline \multirow[b]{2}{*}{ COUNTRY } & \multicolumn{2}{|c|}{ GDP growth rate (\% change) } \\
\hline & $1991-2000$ & 2001-2009 \\
\hline Bangladesh & $54.64 \%$ & $57.69 \%$ \\
\hline Botswana & $54.40 \%$ & $36.53 \%$ \\
\hline Brazil & $26.57 \%$ & $30.49 \%$ \\
\hline Chile & $72.19 \%$ & $32.77 \%$ \\
\hline China & $146.85 \%$ & $126.32 \%$ \\
\hline Costa Rica & $62.32 \%$ & $43.25 \%$ \\
\hline Ethiopia & $41.30 \%$ & $87.65 \%$ \\
\hline Ghana & $44.72 \%$ & $58.03 \%$ \\
\hline Hong Kong & $38.94 \%$ & $37.81 \%$ \\
\hline India & $68.34 \%$ & $82.87 \%$ \\
\hline Indonesia & $38.80 \%$ & $51.14 \%$ \\
\hline Israel & $62.55 \%$ & $30.14 \%$ \\
\hline Japan & $8.84 \%$ & $4.15 \%$ \\
\hline Korea (Rep.) & $64.95 \%$ & $35.75 \%$ \\
\hline Malawi & $29.00 \%$ & $54.64 \%$ \\
\hline Malaysia & $81.37 \%$ & $45.46 \%$ \\
\hline Mauritius & $60.96 \%$ & $33.41 \%$ \\
\hline Rwanda & $6.36 \%$ & $77.59 \%$ \\
\hline Singapore & $94.82 \%$ & $58.54 \%$ \\
\hline South Africa & $21.00 \%$ & $33.26 \%$ \\
\hline Sri Lanka & $58.96 \%$ & $55.65 \%$ \\
\hline Tanzania & $32.23 \%$ & $72.76 \%$ \\
\hline Thailand & $42.45 \%$ & $38.71 \%$ \\
\hline Turkey & $41.80 \%$ & $42.21 \%$ \\
\hline Uganda & $82.49 \%$ & $83.79 \%$ \\
\hline Vietnam & $95.89 \%$ & $76.58 \%$ \\
\hline Taiwan & $69.66 \%$ & $33.97 \%$ \\
\hline
\end{tabular}

Source of data: WDI Dataset 2011 (World Bank): www.data.worldbank.org; World Economic Outlook Database from the IMF (GDP constant in Taiwan national currency - billions 1980) [Accessed through ESDS UK]

\begin{tabular}{|c|c|c|}
\hline & \multicolumn{2}{|c|}{ School enrolment, tertiary (\% change) } \\
\hline COUNTRY & $90-99 / 91-00$ & $00-09 / 01-10$ \\
\hline Bangladesh & $23.59 \%$ & $62.01 \%$ \\
\hline Botswana & $34.99 \%$ & $42.71 \%$ \\
\hline Brazil & $42.76 \%$ & $133.95 \%$ \\
\hline Chile & $74.94 \%$ & $45.55 \%$ \\
\hline China & $160.96 \%$ & $214.64 \%$ \\
\hline Costa Rica & - & - \\
\hline Ethiopia & $55.39 \%$ & $274.55 \%$ \\
\hline Ghana & - & $55.54 \%$ \\
\hline Hong Kong & - & $84.47 \%$ \\
\hline India & $56.77 \%$ & $40.94 \%$ \\
\hline Indonesia & $52.29 \%$ & $58.27 \%$ \\
\hline Israel & $43.62 \%$ & $23.45 \%$ \\
\hline Japan & $61.24 \%$ & $28.44 \%$ \\
\hline Korea (Rep.) & $104.53 \%$ & $35.23 \%$ \\
\hline Malawi & $-43.74 \%$ & $70.22 \%$ \\
\hline Malaysia & $219.44 \%$ & $58.63 \%$ \\
\hline Mauritius & $229.33 \%$ & $151.27 \%$ \\
\hline Rwanda & $69.86 \%$ & $246.63 \%$ \\
\hline Singapore & - & - \\
\hline South Africa & - & - \\
\hline Sri Lanka & - & - \\
\hline Tanzania & $90.40 \%$ & $162.62 \%$ \\
\hline Thailand & $111.73 \%$ & $21.38 \%$ \\
\hline Turkey & $81.79 \%$ & $77.42 \%$ \\
\hline Uganda & $91.78 \%$ & $61.45 \%$ \\
\hline Vietnam & $388.78 \%$ & - \\
\hline Taiwan & - & - \\
\hline
\end{tabular}

Source of data: WDI Dataset 2011 (World Bank): www.data.worldbank.org 


\begin{tabular}{|c|c|c|}
\hline & \multicolumn{2}{|c|}{ GINI Index (\% change) - W/GMID } \\
\hline COUNTRY & $90-99$ / 91-00 & 00-09 / 01-10 \\
\hline Bangladesh & $17.13 \%$ & $0.98 \%$ \\
\hline Botswana & - & - \\
\hline Brazil & $-7.80 \%$ & $-11.74 \%$ \\
\hline Chile & $4.33 \%$ & $-10.17 \%$ \\
\hline China & $-33.66 \%$ & $28.89 \%$ \\
\hline Costa Rica & $-4.70 \%$ & $4.28 \%$ \\
\hline Ethiopia & $-24.92 \%$ & $-0.67 \%$ \\
\hline Ghana & $-10.97 \%$ & $5.20 \%$ \\
\hline Hong Kong & $10.12 \%$ & $1.41 \%$ \\
\hline India & $8.62 \%$ & $4.50 \%$ \\
\hline Indonesia & $-15.57 \%$ & $4.17 \%$ \\
\hline Israel & $8.12 \%$ & $0.77 \%$ \\
\hline Japan & $0.00 \%$ & $5.11 \%$ \\
\hline Korea (Rep.) & $2.77 \%$ & $5.17 \%$ \\
\hline Malawi & - & $-22.44 \%$ \\
\hline Malaysia & $-1.34 \%$ & $3.29 \%$ \\
\hline Mauritius & - & - \\
\hline Rwanda & - & - \\
\hline Singapore & $3.50 \%$ & $2.34 \%$ \\
\hline South Africa & $-7.37 \%$ & $0.00 \%$ \\
\hline Sri Lanka & $-15.02 \%$ & $45.87 \%$ \\
\hline Tanzania & $-41.26 \%$ & - \\
\hline Thailand & $-10.00 \%$ & $6.56 \%$ \\
\hline Turkey & $-18.11 \%$ & $3.16 \%$ \\
\hline Uganda & $28.11 \%$ & $-18.86 \%$ \\
\hline Vietnam & $25.08 \%$ & $4.88 \%$ \\
\hline Taiwan & $9.76 \%$ & $0.88 \%$ \\
\hline
\end{tabular}

Source of data: UNDP Stats; WDI Dataset 2011 (World Bank): www.data.worldbank.org; World Income Inequality Database (WIID2):

http://www.wider.unu.edu/research/Database/en_GB/wiid/; Global Market Information 


\begin{tabular}{|c|c|c|}
\hline \multirow[b]{2}{*}{ COUNTRY } & \multicolumn{2}{|c|}{$\begin{array}{l}\text { Income share held by lowest } 10 \% \text { (\% change) } \\
\text { W/GMID }\end{array}$} \\
\hline & $90-99 / 91-00$ & 00-09 / 01-10 \\
\hline Bangladesh & $-4.18 \%$ & $-1.31 \%$ \\
\hline Botswana & - & - \\
\hline Brazil & $33.33 \%$ & $22.04 \%$ \\
\hline Chile & $21.53 \%$ & $4.00 \%$ \\
\hline China & $-34.38 \%$ & $-53.85 \%$ \\
\hline Costa Rica & $28.49 \%$ & $-37.21 \%$ \\
\hline Ethiopia & $11.55 \%$ & $77.11 \%$ \\
\hline Ghana & $-15.59 \%$ & $-7.62 \%$ \\
\hline Hong Kong & $-40.00 \%$ & $-16.67 \%$ \\
\hline India & $-21.88 \%$ & $-31.03 \%$ \\
\hline Indonesia & $-30.60 \%$ & $-19.23 \%$ \\
\hline Israel & $-14.29 \%$ & $-25.39 \%$ \\
\hline Japan & $0.00 \%$ & $-8.33 \%$ \\
\hline Korea (Rep.) & $-14.81 \%$ & $-13.04 \%$ \\
\hline Malawi & $53.95 \%$ & - \\
\hline Malaysia & $6.67 \%$ & $-20.00 \%$ \\
\hline Mauritius & - & - \\
\hline Rwanda & - & $-26.99 \%$ \\
\hline Singapore & $-23.08 \%$ & $22.22 \%$ \\
\hline South Africa & $238.38 \%$ & $0.00 \%$ \\
\hline Sri Lanka & $8.80 \%$ & $-18.49 \%$ \\
\hline Tanzania & - & - \\
\hline Thailand & $-77.70 \%$ & $-47.83 \%$ \\
\hline Turkey & $43.75 \%$ & $4.76 \%$ \\
\hline Uganda & $12.95 \%$ & $85.29 \%$ \\
\hline Vietnam & $-36.00 \%$ & $-7.14 \%$ \\
\hline Taiwan & $-6.63 \%$ & $-37.02 \%$ \\
\hline
\end{tabular}

Source of data: WDI Dataset 2011 (World Bank): www.data.worldbank.org; World Income Inequality Database (WIID2): http://www.wider.unu.edu/research/Database/en_GB/wiid/ (Variable D1 in this database); Global Market Information Database [Accessed through ESDS UK] 


\section{esid}

identifying routes to social justice

\section{The Effective States and Inclusive Development Research Centre}

The Effective States and Inclusive Development Research Centre (ESID) aims to improve the use of governance research evidence in decision-making. Our key focus is on the role of state effectiveness and elite commitment in achieving inclusive development and social justice.

ESID is a partnership of highly reputed research and policy institutes based in Africa, Asia, Europe and North America. The lead institution is the University of Manchester.

The other founding institutional partners are:

- $\quad$ BRAC Development Institute, BRAC University, Dhaka

- Institute for Economic Growth, Delhi

- Department of Political and Administrative Studies, University of Malawi, Zomba

- $\quad$ Center for Democratic Development, Accra

- $\quad$ Centre for International Development, Harvard University, Boston

In addition to its institutional partners, ESID has established a network of leading research collaborators and policy/uptake experts. 